\title{
Use of Surface and Borehole Geophysicel Surveys to Determine Fracture Orientation and Other Site Characteristics in Crystalline Bedrock Terrain, Millville and Uxbridge, Massachusetts
}

\section{By BRUCE P. HANSEN and JOHN W. LANE}

U.S. Geological Survey

Water-Resources Investigations Report 95-4121

Prepared in cooperation with

MASSACHUSETTS DEPARTMENT OF ENVIRONMENTAL PROTECTION, BUREAU OF WASTE SITE CLEANUP

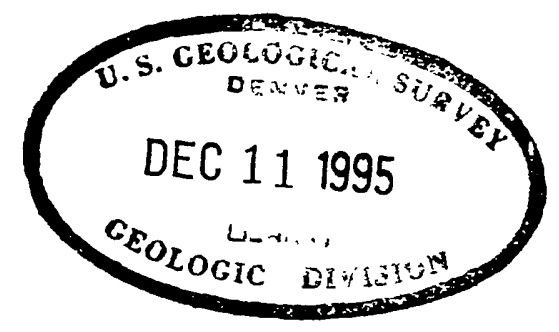

Marlborough, Massachusetts 


\title{
U.S. DEPARTMENT OF THE INTERIOR \\ BRUCE BABBITT, Secretary
}

\author{
U.S. GEOLOGICAL SURVEY \\ Gordon P. Eaton, Director
}

For additional information, write to:

Copies of this report can be purchased from:

Chief, Massachusetts-Rhode Island District

U.S. Geological Survey

U.S. Geological Survey

Earth Science Information Center

Water Resources Division

Open-File Reports Section

28 Lord Road, Suite 280

Box 25286, MS 517

Marlborough, MA 01752

Denver Federal Center

Denver, CO 80225 


\section{CONTENTS}

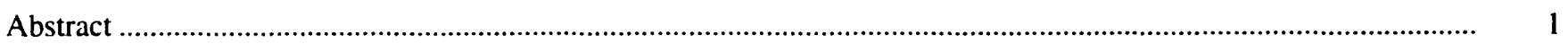

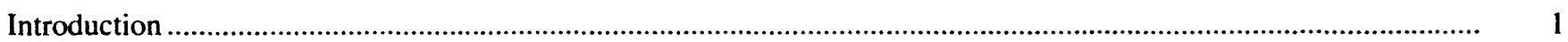

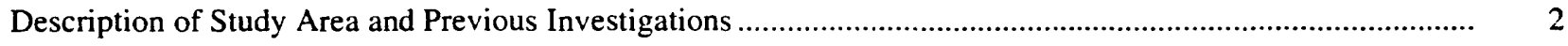

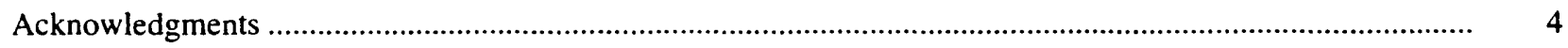

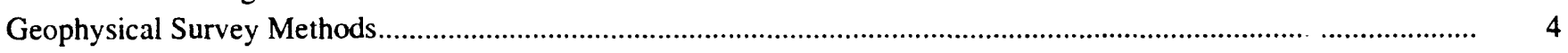

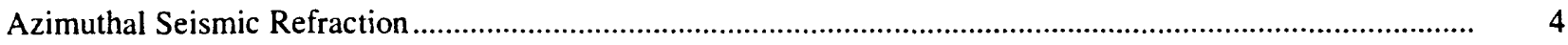

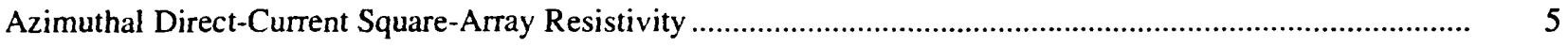

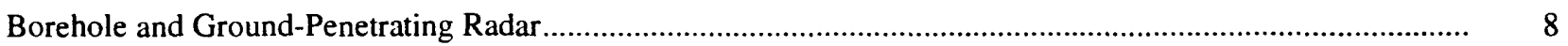

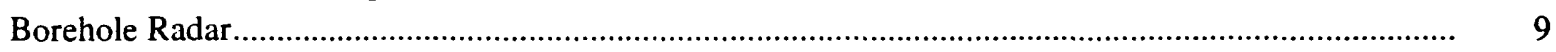

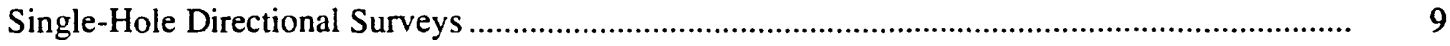

Cross-Hole Tomography Surveys ...........................................................................................

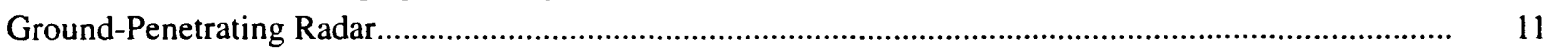

Surface and Borehole Geophysical Surveys to Determine Fracture Orientation ..................................................... 11

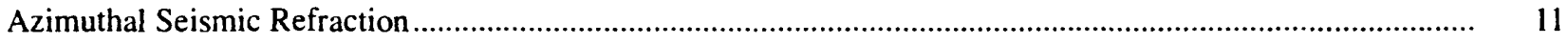

Azimuthal Direct-Current Square-Array Resistivity .................................................................................. 12

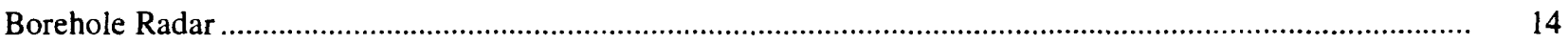

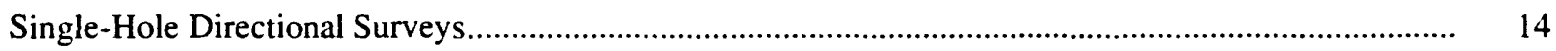

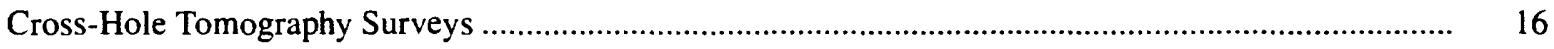

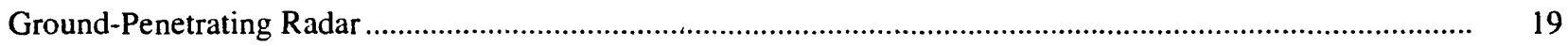

Correlation of Fracture Orientation Results.................................................................................... 19

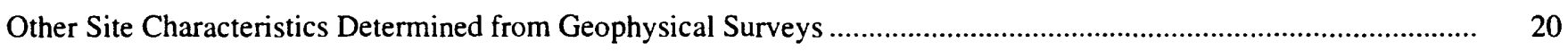

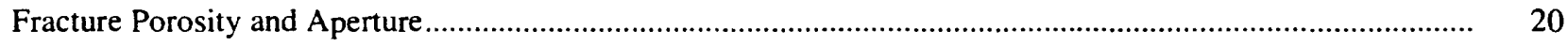

Depth to Bedrock

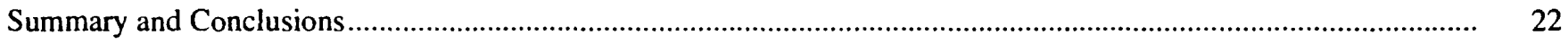

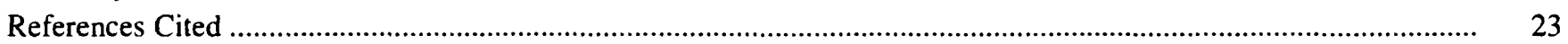

\section{FIGURES}

1. Map showing location of study area, geophysical surveys, and data-collection sites

in Millville and Uxbridge, Massachusetts

2-4. Diagrams showing:

2. Configuration and orientation of seismic-refraction lines for azimuthal seismic velocity surveys

3. Configuration and orientation of dc-resistivity square-arrays for azimuthal resistivity profiling and sounding surveys

4. Directional borehole-radar antenna configuration and typical record of radar reflections received from single-hole survey

5,6. Azimuthal plots of

5. Seismic velocity in bedrock determined with the Hobson-Overton method of velocity analysis, sites 1-3, Uxbridge, Massachusetts.

6. Apparent resistivity determined from square-array surveys at sites 1-3, Uxbridge, Massachusetts............... 13

7. Borehole-radar record and interpreted location of reflectors from well KR30, Uxbridge, Massachusetts .............. 14

8. Cross section showing common reflectors identified in single-hole radar survey in wells KR30 and KR30A, Uxbridge, Massachusetts 


\title{
FIGURES-Continued
}

9. Diagram showing location of common vertical reflector identified in single-hole radar survey in wells KR29, KR30, and KR30A, Uxbridge, Massachusetts.

10. Tomogram of radar-wave attenuation, televiewer logs, and water-yielding zones in the cross section along wells KR30A, KR30, and KR29, Uxbridge, Massachusetts.

11. Diagram showing 100-Megahertz ground-penetrating radar record and interpreted geologic cross section $A-A$ ' along Conestoga Drive, Uxbridge, Massachusetts

12. Geologic section $C-C^{\prime}$ interpreted from seismic-refraction survey data at site 1 on Conestoga Drive, Uxbridge, Massachusetts

13. Diagram showing 100-Megahertz ground-penetrating radar record and interpreted geologic cross section $B-B^{\prime}$ along Conestoga Drive, Uxbridge, Massachusetts

\section{TABLES}

1. Approximate values of conductivity, relative dielectric permittivity, and radar-wave velocity for selected materials

2. Radar reflectors identified in single-hole directional radar surveys of wells KR29, KR30 and KR30A, Uxbridge, Massachusetts

3. Primary and secondary fracture-strike orientations determined from azimuthal seismic refraction and azimuthal square-array resistivity surveys, Uxbridge, Massachusetts

4. Average high-angle bedrock fracture characteristics determined from square-array resistivity survey data from sites 1-3, Uxbridge, Massachusetts

CONVERSION FACTORS, VERTICAL DATUM, AND ABBREVIATIONS

\begin{tabular}{ccl}
\hline Multiply & By & To Obtain \\
\hline foot $(\mathrm{ft})$ & 0.3048 & meter \\
foot per nanosecond $(\mathrm{ft} / \mathrm{ns})$ & 0.3048 & meter per nanosecond \\
foot per second $(\mathrm{ft} / \mathrm{s})$ & 0.0004 & kilometer per second \\
ohm foot (ohm ft) & 1.609 & ohm meter \\
Temperature in degrees Fahrenheit $\left({ }^{\circ} \mathrm{F}\right)$ can be converted to degrees Celsius $\left({ }^{\circ} \mathrm{C}\right)$ & as follows: ${ }^{\circ} \mathrm{C}=5 / 9\left({ }^{\circ} \mathrm{F}-32\right)$. & \\
& &
\end{tabular}

\section{Vertical Datum}

Sea level: In this report "sea level" refers to the National Geodetic Vertical Datum of 1929 (NGVD of 1929)—a geodetic datum derived from a general adjustment of the first-order level nets of both the United States and Canada, formerly called Sea Level Datum of 1923.

\author{
Abbreviations: \\ degree $\left({ }^{\circ}\right)$ \\ megahertz $(\mathrm{MHz})$ \\ mho per meter $(\mathrm{mho} / \mathrm{m})$ \\ microgram per liter $(\mu \mathrm{g} / \mathrm{L})$
}




\title{
Use of Surface and Borehole Geophysical Surveys to Determine Fracture Orientation and Other Site Characteristics in Crystalline Bedrock Terrain, Millville and Uxbridge, Massachusetts
}

\author{
By Bruce P. Hansen and John W. Lane
}

\begin{abstract}
Four geophysical techniques were used to determine bedrock fracture orientation and other site characteristics that can be used to determine ground-water movement and contaminant transport at a fractured crystalline bedrock site in Millville and Uxbridge, Massachusetts. Azimuthal seismic-refraction and azimuthal square-array direct current resistivity surveys were conducted at three sites. Borehole-radar surveys were conducted in a cluster of three wells. Ground-penetrating radar surveys were conducted along roads in the study area.
\end{abstract}

Azimuthal seismic-refraction data indicated a primary fracture strike from 56 to 101 degrees at three sites. Graphical and analytical analysis of azimuthal square-array resistivity data indicated a primary fracture strike from 45 to 90 degrees at the same three sites. Directional borehole-radar data from three wells indicated 46 fractures or fracture zones located as far as 147 feet from the surveyed wells. Patterns of low radar-wave velocity and high radar-wave attenuation from cross-hole radar surveys of two well pairs were interpreted as a planar fracture zone that strikes 297 degrees and dips 55 degrees south. Ground-penetrating radar surveys with 100-megahertz antennas penetrated as much as 150 feet of bedrock, where the bedrock surface was at or near land surface. Horizontal and subhorizontal fractures were observed on the ground-penetrating radar records at numerous locations. Correlation of data sets indicates good agreement and indicates primary high-angle fracturing striking east-northeast. Secondary bedrock porosity and average fracture aperture associated with high-angle fracturing and determined from square-array resistivity data averaged 0.0044 and 0.0071 foot.

Depths to bedrock determined from the ground-penetrating radar records were 0 to 27 feet below land surface along most of the area surveyed. A bedrock depth from 45 to 50 feet b low land surface was determined along one section of Conestoga Drive. This buried bedrock depression may be part of a bedrock channel that could be a pathway or sink for contamination moving along the bedrock surface.

\section{INTRODUCTION}

Contamination of ground water in fractured crystalline bedrock is a problem at many sites in New England. Determining the rate and direction of groundwater flow, contaminant transport, and ultimately, designing site remediation plans requires knowledge about fracture characteristics. The predominant orientation of fractures or fracture zones may result in significant anisotropy (properties that differ according to direction of measurement) in ground-water-flow characteristics in bedrock. Geophysical methods can indicate anisotropy of physical properties of bed -ock caused by fractures, and therefore, may also indicate a preferred direction of ground-water flow. Geophysical 
methods have been successfully used to detect fracture characteristics, including fracture location and orientation. One conclusion of most geophysical studies is that the effect of fracturing on changes in physical properties of bedrock is small (Lieblich and others, 1992a). As a result, interference from natural and cultural sources may obscure or degrade geophysical data so that clear responses from fractures are not detected. Integration (cross correlation) of the results from as many independent geophysical survey methods as possible should improve confidence in the orientation and location of fractures and possibly improve resolution (degree to which individual features can be detected) over that from a single method. These multiple method surveys should be conducted at the same location or in as close proximity to one another as practically possible, so that the same or approximately similar volume of bedrock is sampled. Few multiple surveys have been conducted in areas underlain by crystalline bedrock.

A site on the border between Millville and Uxbridge, in south-central Massachusetts, where chlorinated hydrocarbons had been detected in water from wells completed in fractured crystalline bedrock, provided an opportunity to demonstrate the application of geophysical methods for characterizing fractures and additional information that also could be used to determine the movement of contaminants at the site. For these purposes, the U.S. Geological Survey (USGS), in cooperation with the Massachusetts Department of Environmental Protection (MDEP), conducted azimuthal seismic-refraction, azimuthal square-array direct current resistivity, borehole radar, and groundpenetrating radar geophysical surveys in Millville and Uxbridge, Massachusetts.

The purpose of this report is to present the methodologies and results of the azimuthal seismic refraction, azimuthal square-array direct current resistivity, borehole radar, and ground-penetrating radar geophysical surveys conducted in Millville and Uxbridge, Massachusetts, from August through December 1993. The report presents selected records of geophysical data, interpretation of fracture or strike location from individual geophysical methods, an integrated interpretation of fracture strike from four geophysical methods, and some additional information from the geophysical surveys that could be used to determine movement of contaminants. The physical characteristics of the study area and a summary of the results of previous investigations also are described.

\section{Description of Study Area and Previous Investigations}

The area of investigation is located in so'th-central Massachusetts, in the towns of Millville and Uxbridge (fig. 1). This area is on the eastern edge of t $\cdot$ New England Central Highlands physiographic province (Denny, 1982), which is typified by slightly elongated low rolling hills with moderate relief. In gereral, the long axes of bedrock hills are oriented north-south and reflect the regional geologic structural trend. Scour and deposition of material during the last period of glaciation has resulted in a north-northwest to nor'hwest orientation of present-day hills. Locally, the relief between the Blackstone River, which drains the area, and the highest hills is about $300 \mathrm{ft}$. The area adjacert to Kempton Road and East Street, where the geophysical surveys were conducted, is on the top and side of a hill with maximum and minimum altitudes of 490 and $300 \mathrm{ft}$ above sea level.

Total concentrations of dissolved chlor nated hydrocarbons, including tetrachloroethylene (PCE), trichloroethylene (TCE), and trichloroethane (TCA), ranged from 0.5 to $1,483,000 \mu \mathrm{g} / \mathrm{L}$ in water samples collected in 1991 (Paul Ollila, Massachusetts Department of Environmental Protection, written commun., 1992). Concentrations in water samples of water were highest in water samples from 27 domestic bedrock wells closest to the probable source of contamination (fig. 1), $500 \mathrm{ft}$ east of the intersection of Kempton Road and Conestoga Drive (HMM Associates, Inc., 1993). Dissolved hydrocarbons were detected in water samples from wells as far as $2,100 \mathrm{ft}$ southwest of the contamination source. Concentrations of dissolved hydrocarbons were not detected but could become contaminated in the future at many additional bedrock wells adjacent to the area with contamination. Preliminary analysis of tree-ring cores collerted near the contamination source indicated that chlorinated hydrocarbons were first discharged from 1974 to 1977 (Thomas M. Yanosky, U.S. Geological Survey, Reston, Va., written commun., 1993). 


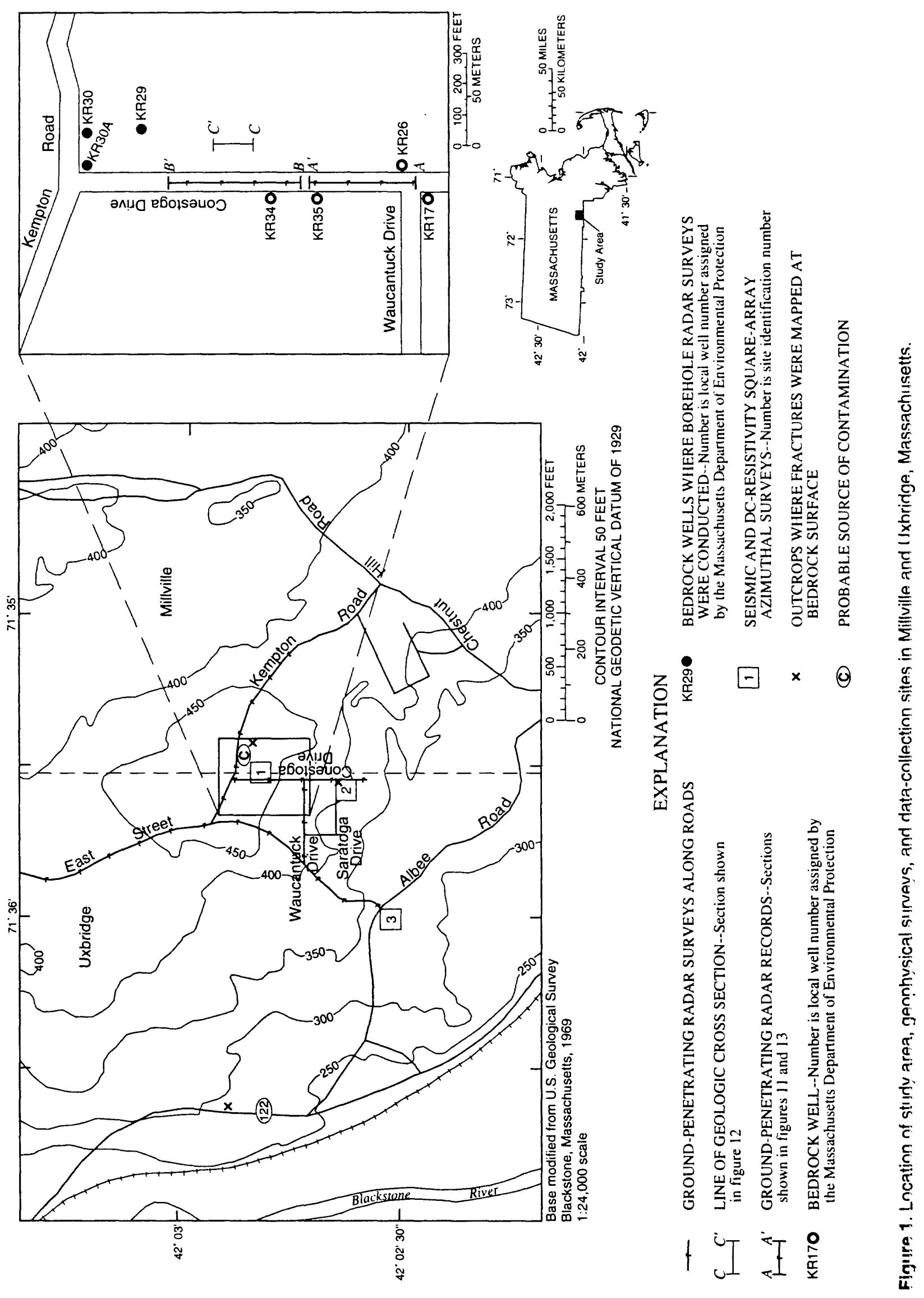


The bedrock map of Massachusetts (Zen and others, 1983) shows the area to be underlain by Milford Granite. Mapping by McKniff (1964) indicates that the bedrock underlying the area is intermixed light-gray, medium- to coarse-grained quartz diorite gneiss and dark-gray to black amphibolite. Paillet and Ollilla (1994) studied well-logging techniques for characterizing fractures and borehole-geophysical applications for understanding how fractures contribute to the dispersal of hydrocarbon contamination in ground water in a fractured, crystalline bedrock aquifer. Paillet and Ollilla (1994) report that:

- quartz diorite gneiss is the most abundant rock type near the site, on the basis of observations of shallow bedrock cores, bedrock outcrops, and rock excavations;

- strike and dip of fractures measured on three outcrops on or adjacent to the site indicate a predominance of high-angle dips with strikes generally oriented east and west at the outcrop at the east end of Saratoga Drive and fracture strikes oriented west and north at the outcrop on Route 122;

- fracture orientation was not consistent for 157 fractures interpreted from televiewer logs of six wells in the study area; and

- orientation was not consistent for 16 hydraulically conductive fractures that were identified by flow-meter logging of six wells.

\section{Acknowledgments}

The authors thank Paul Ollila, Nicoles Child, and Wendy Shaughnessy of the Massachusetts Department of Environmental Protection, Bureau of Waste Site Cleanup, who provided valuable information and assistance. Special appreciation is extended to the landowners who granted the USGS permission to conduct geophysical surveys on their property.

\section{GEOPHYSICAL SURVEY METHODS}

Different rock types and geologic structure have different physical properties. These different properties are utilized in the proper application of geophysical methods. The physical properties of interest for this study were seismic velocity, electrical resistivity, and relative dielectric permittivity. The geophysical methods applied in this study were seismic refraction, direct current resistivity, and radar. These were selected because of their successful use for fracture detection in previous investigations. The theory of each method is briefly described, and the reader can find detailed descriptions of the theory and methods in references cited in the text. The methods are described in detail relative to the availability of easily accessible references describing each method.

\section{Azimuthal Seismic Refraction}

Refracted waves of seismic energy are utilized in the seismic-refraction method, which is based on the time of travel of energy from a point source through the ground. This method requires the assumption of a layered earth in which the velocity of seismic energy increases with depth in each successive layer. W'hen this assumption is met, seismic energy originating from a sound source (a shot) travels downward into the ground until meeting a refracting surface such as the tcp of bedrock. Energy refracted along this surface continually generates seismic waves that travel upward to land surface, where its arrival is detected by a series of geophones. The arrival times can be used to calculate the velocity of sound through the different layers through which the seismic energy has passed, and consequently, the depth of each layer can be determined. Descriptions of seismic-refraction theory and interpretation methods are given by Redpath (1973), Dobrin (1976), I Iooney (1981), and Haeni (1988).

Seismic energy generated at a point is com zosed of several wave forms. For this study, the compressional wave (p-wave) component of seismic energy was used. The compressional wave velocity is hencefortl referred to as seismic velocity.

In the application of the azimuthal seismicrefraction technique, it is assumed that the directional velocity of seismic energy in bedrock is affected by an anisotropic distribution of fractures that inters $: c t$ the bedrock surface and that differences in directional velocity are detectable. Data for azimuthal seismicrefraction surveys were collected from several seismic lines oriented at equal angular intervals around a common center point at a site. At any locatior. the configuration of the seismic line (geophone spacing and 
shot point location) will be determined by geohydrologic characteristics, including type and thickness of surficial deposits and depth to the water table. The directional velocity of seismic energy in bedrock is determined for each seismic line. For a single subvertical set of fractures, maximum velocity is along the fracture strike direction and minimum velocity is orthogonal to the fracture strike direction. This difference in directional velocity is referred to as the velocity anisotropy. This anisotropy is described by the ratio of maximum and minimum velocity, but this ratio is a scalar indicator that is properly expressed as a tensor. Some of the limitations of this method include (1) multiple fracture sets that may result in a complex azimuthal distribution of seismic velocity, (2) velocity and (or) thickness inhomogeneities in the material overlying a reflector that also can cause anisotropic azimuthal velocity determinations, and (3) the effect of single fractures or small, isolated fracture zones that are unlikely to be detected because the velocity changes caused by these zones generally are too small to be detected. Despite these limitations, refraction surveys where fractures have been detected have been conducted by Bamford and Nunn (1979) in carbonate rock, Park and Simmons (1982) and Lieblich and others (1992a, 1992b) in crystalline rock with glacial overburden, and Imse and Levine (1985) in carbonate rock with glacial overburden.

For this study, azimuthal seismic-refraction data were acquired at three sites (fig. 1). At each site, eight seismic lines oriented in $22.5^{\circ}$ increments about a common center point were used (fig. 2). Each line consisted of 24 geophones with a 5-foot spacing. Five sets of time-distance data were collected for each line. Two shots were located 5 and $25 \mathrm{ft}$ from each end of the geophone lines and one shot was located in the center of the line, for a total of five shots along each line. A sledge hammer striking a metal plate on the ground provided the source of seismic energy at each shot location. A 24-channel, signal-enhancement seismograph was used to record data. Elevations were recorded for each shot and geophone location to 0.01 -foot accuracy. Seismic velocity was determined on the basis of the SIPT computer program (Scott and others, 1972; Scott, 1977; and Haeni and others, 1987a),

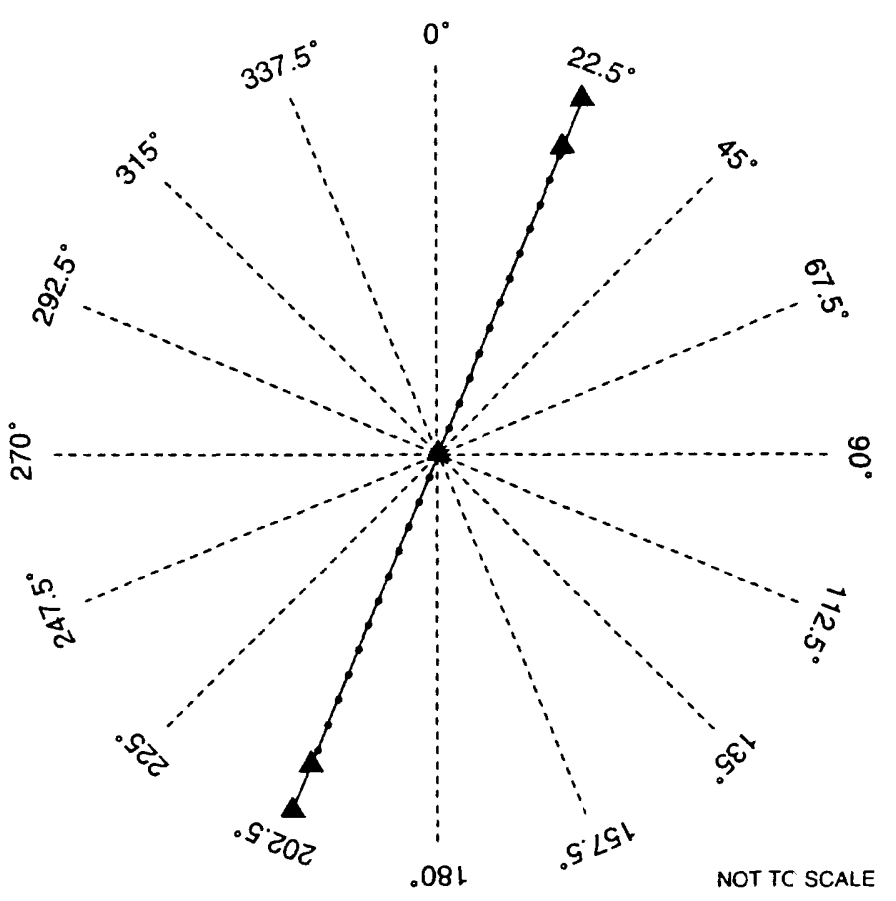

\section{EXPLANATION}

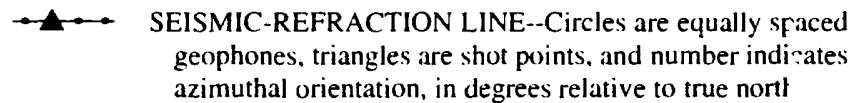

-..- INCREMENTAL ORIENTATION OF SEISMIC. REFRACTION LINES--Number indicates azimuthal orientation, in degrees relative to true north

Figure 2. Configuration and orientation of seismic-refraction lines for azimuthal seismic velocity surveys.

which incorporates delay-time and ray tracing proce tures and uses linear regression and the Hobson Overton mothod of velocity analysis. For graphic visualization and interpretation, seismic velocities and seismic-line orientation were plotted.

\section{Azimuthal Direct-Current Square-Array Resistivity}

The resistivity (direct-current resistivity) method, mainly using collinear (Wenner- or Schlumberger-ty'pe) arrays has been extensively used in geologic and hydrologic investigations to determine subsurface layered earth configurations and (or) water-quality conditions. Detailed explanations of the theory, methods, and applications are given in many geophysics text books, such as Hanse 7 and others (1967) and Zody and others (1974). Resistivity 
methods have been successfully applied to detect fractures by a number of investigators, including Risk (1975), McDowell (1979), Palacky and others (1981), Soonawala and Dence (1981), Taylor (1982), Mallik and others (1983), Leonard-Mayer (1984a, 1984b), Ogden and Eddy (1984), Taylor and Fleming (1988), Lieblich and others (1991, 1992a, 1992b), and Ritzi and Andolsek (1992). Most of these investigators applied collinear arrays rotated about a fixed center point to measure directional variations in apparent resistivity that are related to sets of similarly oriented steeply dipping fractures (Lewis and Haeni, 1987).

The square-array method (square-array directcurrent resistivity) of measuring apparent earth resistivity was originally developed to provide directionally stable apparent resistivity values for layered-earth interpretation in situations of dipping subsurface bedding or foliation (Habberjam and Watkins, 1967). When variations in azimuthal resistivity are detected over an anisotropic earth and the variations are related to sets of similarly oriented steeply dipping fractures, the squarearray interpretive methods of Habberjam (1972, 1975, 1979) and Taylor (1984) can be used to determine fracture strike and to estimate secondary porosity.

In comparison with other resistivity methods, the square-array has been shown to be more sensitive to apparent resistivity anisotropy (the ratio of apparent resistivity measured perpendicular and parallel to fracture strike) (Habberjam, 1972; LeMasne, 1979; Darboux-Afouda and Louis, 1989). The high apparent anisotropy measured with the square array is advantageous because the typically small anisotropy is less likely to be obscured by heterogeneities in bedrock or overburden, bedrock relief, cultural noise, electrode placement error, or other sources of noise that can cause variations in azimuthal resistivity. In addition, the square-array method requires about 65 percent less surface area than an equivalent survey with a collinear array.

Darboux-Afouda and Louis (1989) and Sehli (1990) used the square-array method to locate productive fractures in crystalline bedrock for ground-water supplies. Recent square-array surveys at the USGS bedrock research site in New Hampshire (Lane and others, 1995) detected fracture orientation that agreed with fracture mapping at nearby bedrock outcrops, azimuthal seismic-refraction surveys, and azimuthal
Schlumberger resistivity soundings. Lane and others (1995) also outline a simplified method of datc analysis to determine fracture strike and secondary porosity.

The square array consists of four electrod $s$ driven into the ground to form a square configuration (fig. 3). The location of all measurements are assigne $f$ to the center point of the square. The array size $(A)$ is the length of a side of the square. Each resistivity measurement consists of measuring current $(I)$ between two current electrodes $(A B)$ and the potential difference between two potential electrodes $(M N)$. Based on these measurements, apparent resistivity is determined using the equation

$$
p a=\frac{K \Delta E}{I}
$$

where $p a$ is apparent resistivity, in ohm-meters;

$K$ is geometric factor for the arricy;

$\Delta E$ is potential difference, in volts: and

$I$ is current, in amperes.

For the square array

$$
K=\frac{2 \pi A}{2-\sqrt{2}}
$$

where $A$ is square-array sidelength, in meters.

For each square, three apparent resistivity measurements are taken (fig. 3). Two measurements (alpha and beta) are perpendicular to each other and parallel to the sides of the square, and a third (gamma) is taken diagonally across the square. The two perpendicular measurements provide information on the directional variations of the subsurface resistivity. The azimuthal orientation of the perpendicular measurements is the line that connects the current electrodes. The diagonal measurement serves as a check on the accuracy of the two perpendicular measurements. In an isotropic medium, the apparent resistivity in the alpha and beta directions are equal and gamma is equal to zero. In a homogeneous, anisotropic medium, the gamma resistivity is equal to the difference between the alpha and beta resistivity. To collect a complete se ${ }^{+}$of azimuthal-profiling data, the array is rotated in equal angular increments around a common center point. To detect vertical (depth) variations in apparent resistivity at each azimuthal orientation, the array is 


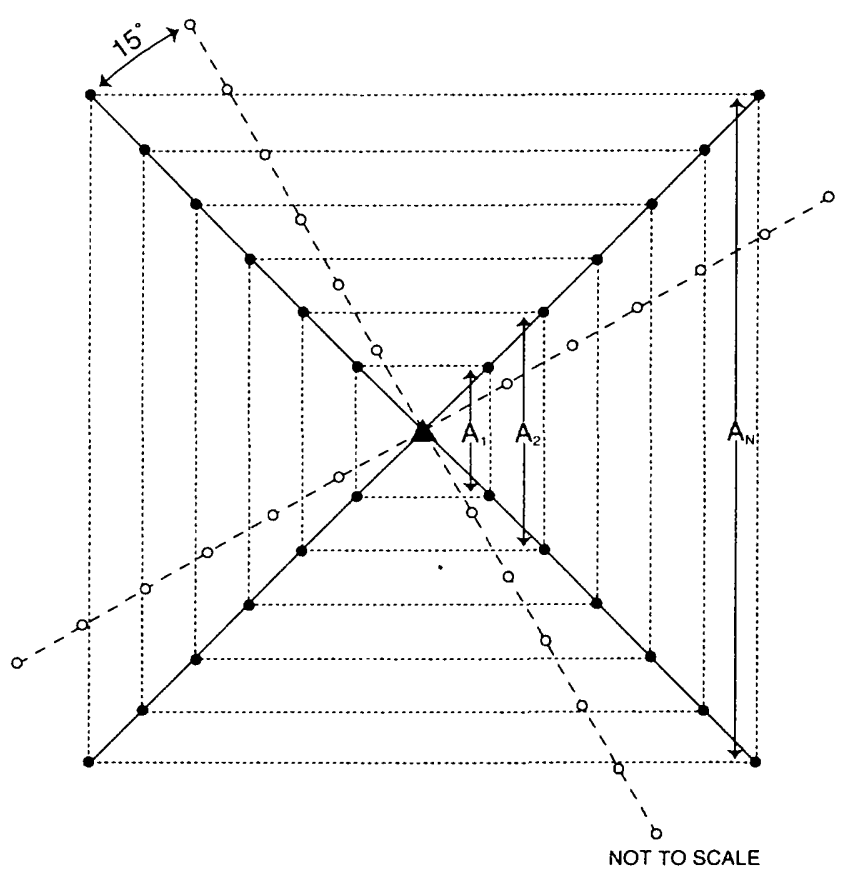

EXPLANATION

CONFIGURATION OF EXPANDED SQUARES

ELECTRODE LOCATIONS--Shown for multiple expanded square array configurations for soundings of apparent resistivity

$\rightarrow \quad$ AZIMUTHS OF $0^{\circ}$ AND $90^{\circ}$

- - - AZIMUTHS OF $15^{\circ}$ AND $105^{\circ}$

$\leftrightarrow A_{\vec{T}}$ LENGTH OF SIDE OF SQUARE ARRAY

- CENTER OF SQUARE ARRAY

ELECTRODE CONFIGURATIONS FOR THE THREE MEASUREMENTS PER SQUARE ARRAY
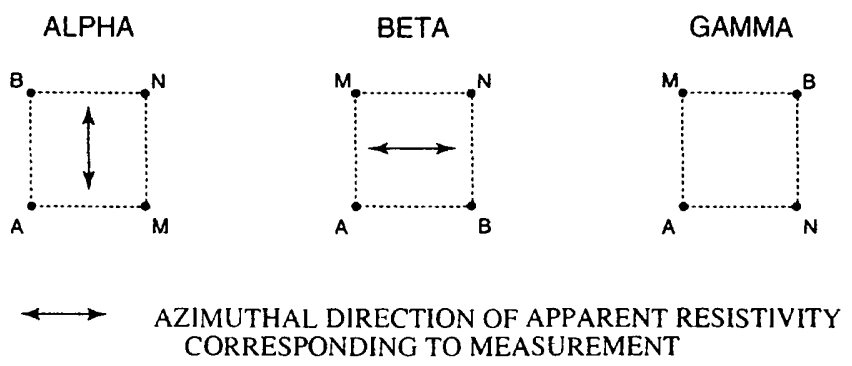

A AND B CURRENT ELECTRODES

MAND N POTENTIAL ELECTRODES

Figure 3. Configuration and orientation of dc-resistivity square-arrays for azimuthal resistivity profiling and sounding surveys. usually expanded symmetrically about the center point in increments of $A$ multiplied by $\sqrt{2}$ (Hal herjam and Watkins, 1967). These resistivity soundings can be interpreted as a function of depth. Each array samples a cube of earth with dimensions approximately equal to the array $A$-spacing.

Fracture strike can be determined graphically or analytically. To graphically interpret fracture st -ike at a site, each apparent resistivity for a given size square and the azimuth of that measurement are plotted. T'e principal fracture strike direction is perpendicular to the direction of maximum resistivity. Data can be analytically interpreted by using directional resistivity data from two squares separated by $45^{\circ}$ (crossec squarearray) and applying equations presented by $\mathrm{Hal}$ herjam (1975) to determine fracture strike.

Secondary porosity resulting from high-angle fracturing was estimated from crossed square-array resistivity and ground-water resistivity data bas $\%$ on methods developed by Taylor (1984) for colliner- arrays and adapted and applied for the square array by Lane and others (1995). This method for determining secondary porosity also uses anisotropy determined from the field data by Habberjam's method (1975). Secondary porosity resulting from horizontal or low-angle factures is not accounted for with this method.

Average fracture aperture of high-angle fractures at survey sites was estimated based on secondary porosity as determined above and fracture-spacing data determined by fracture mapping at nearby bedrock outcrops. Fracture aperture is equal to the porosity divided by the number of fractures per unit of length.

For this study, square-array data were collested at the three sites shown in figure 1. Azimuthal profiling was accomplished by rotating the array in $15^{\circ}$ increments, giving 12 directional apparent-resistivity measurements and six square arrays for each $A$-spacing. At each azimuthal orientation, sounding (depth) data were collected from 6 to 7 individual arrays with $A$-spacing ranging from 16 to $112 \mathrm{ft}$. Secondary porosity was determined from ground-water resistivity data from borehole fluid-resistivity logs conducted in the area (Bruce P. Hansen, U.S. Geological Survey, written commun., 1994). Fracture apertures were estimated from fracture-spacing data from outcrop mapping (Paul Ollila, Massachusetts Department of Environmental Protection, written commun., 1994). 


\section{Borehole and Ground-Penetrating Radar}

Pulses of radio-frequency energy are transmitted into the ground with ground-penetrating radar. This energy travels through the ground until it arrives at an interface with different electrical properties. At this interface, some of the electromagnetic energy is reflected back toward the transmitting antenna and some continues farther into the ground. Geologic materials have varying electrical properties, which are determined by water content, lithology, structure, foliation, dissolved minerals in ground water, and expansive-clay and heavy-mineral content (Wright and others, 1984; Olhoeft, 1984, 1986; Haeni and others, 1987b). The reflected energy received by an antenna is amplified, converted to audio frequency range, recorded, processed, and displayed on a monitor or graphic recorder. The record shows the relative amplitude of the reflected signal and the total traveltime for the signal to pass through the geologic subsurface materials, reflect from electrical interfaces, and return to the antenna. The twoway traveltime, which is measured in nanoseconds (1 nanosecond $=10^{-9}$ second) and the relative dielectric permittivity are used to compute the distance to a reflector by means of the equations

$$
d=\frac{V t}{2}
$$

and

$$
V=\frac{c}{\varepsilon^{0.5}}
$$

where $\quad d$ is distance to the reflector, in feet;

$V$ is electromagnetic-wave velocity, in feet per nanosecond;

$t$ is two-way traveltime, in nanoseconds;

$c$ is velocity of light in free space (0.98 ft per nanosecond); and

$\varepsilon \quad$ is relative dielectric permittivity.

Dielectric permittivity is a measure of the capacity of a material to store a charge when an electric field is applied to it relative to the same capacity in a vacuum (Sheriff, 1984). Approximate values of relative dielectric permittivities and radar-wave velocities are shown in table 1.
Table 1. Approximate values of conductivity, relative dielectric permittivity, and radar-wave velocity for selected materials

[Data from Ulriksen (1982); Markt (1988). ft/ns, foot per nanosecond;

\begin{tabular}{|c|c|c|c|}
\hline Material & $\begin{array}{l}\text { Conductivity } \\
(\mathrm{mho} / \mathrm{m})\end{array}$ & $\begin{array}{c}\text { Relative } \\
\text { dielectric } \\
\text { permittivity } \\
\text { (dimension- } \\
\text { less) }\end{array}$ & $\begin{array}{l}\text { Fadar wave } \\
\text { velocity } \\
\text { (ft/ns) }\end{array}$ \\
\hline Air & 0 & 1 & 0.98 \\
\hline Pure water & $10^{-4}$ to $3 \times 10^{-2}$ & 81 & 0.11 \\
\hline Sea water & 4 & 81 & 0.11 \\
\hline Freshwater ice & $10^{-3}$ & 4 & 0.49 \\
\hline Sand (dry) & $10^{-7}$ to $10^{-3}$ & 4 to 6 & 0.49 to 0.40 \\
\hline Sand (saturated) & $10^{-4}$ to $10^{-2}$ & 30 & 0.17 \\
\hline Silt (saturated) & $10^{-3}$ to $10^{-2}$ & 10 & 0.31 \\
\hline Clay (saturated) & $10^{-1}$ to 1 & 8 to 12 & 0.35 to 0.28 \\
\hline $\begin{array}{l}\text { Rich agricul- } \\
\text { tural soil }\end{array}$ & $10^{-2}$ & 15 & 0.25 \\
\hline Sandstone (wet) & $4 \times 10^{-2}$ & 6 & 0.40 \\
\hline Shale (wet) & $10^{-2}$ & 7 & 0.37 \\
\hline Limestone (dry) & $10^{-9}$ & 7 & 0.37 \\
\hline Limestone (wet) & $2.5 \times 10$ & 8 & 0.35 \\
\hline Basalt (wet) & $10^{-2}$ & 8 & 0.35 \\
\hline Granite (dry) & $10^{-8}$ & 5 & 0.44 \\
\hline Granite (wet) & $10^{-3}$ & 7 & 0.37 \\
\hline Bedded salt & $10^{-5}$ to $10^{-4}$ & 3 to 6 & 0.57 to 0.40 \\
\hline
\end{tabular}
$\mathrm{mho} / \mathrm{m}, \mathrm{mho} / \mathrm{meter}$ ]

Transmission frequencies used in radcr surveys range from 20 to $1,000 \mathrm{MHz}$. The frequency used for a given investigation is selected to provide an acceptable compromise between high resolution (the degree to which individual features can be detected) and deep penetration (distance radar wave travels into rock). The resolution is theoretically equal to the wavelength $(\lambda)$ of the radar wave divided by 4 (Sheriff, 1984) but is practically limited to $\lambda / 3$ to $\lambda / 2$ (Trabant, 1984). The wavelength is determined based on the equation

$$
\lambda=\frac{V}{f},
$$


where $\lambda$ is the electromagnetic wavelength, in feet;

$V$ is the electromagnetic wave velocity, in feet per second; and

$f$ is the electromagnetic frequency, in cycles per second.

For the range of frequencies used for radar surveys (20 to $1,000 \mathrm{MHz}$ ), resolution in a dry granite ranges from 10.9 to $0.15 \mathrm{ft}$. High-frequency signals produce high-resolution records but have a limited depth of penetration. The principal factor limiting the depth of penetration of radar waves is the attenuation of electromagnetic waves by earth materials. Radar-signal penetration depends on electrical conductivity of earth materials and frequency of the radar wave. Studies in areas of low electrical-conductivity material have reported depths of penetration ranging from $137 \mathrm{ft}$ in gneiss and amphibolite (Lane and others, 1994) to $90 \mathrm{ft}$ in clay-free sand and gravel (Wright and others, 1984; Olhoeft, 1984, 1986). The penetration depth of radar waves can be less than $3 \mathrm{ft}$ in highly conductive materials, such as clay-rich materials (Olhoeft, 1984; Wright and others, 1984). Approximate values of conductivity for selected materials are listed in table 1 .

\section{Borehole Radar}

Short-pulse borehole-radar systems and methods have been developed in the United States (Rubin and others, 1978; Wright and Watts, 1982) and in Sweden (Nilsson, 1983; Olsson and others, 1988). Single-hole reflection and cross-hole tomography methods to detect bedrock fractures have been applied at high-level nuclear-waste sites (Bradley and Wright, 1987; Olsson and others, 1988, 1992a, 1992b; Holloway and others, 1992). Recently, these methods have been applied in shallow ground-water-contamination studies (Niva, 1993; Lane and others, 1994).

For this study, single-hole directional and crosshole tomographic borehole-radar surveys were conducted in three wells near the intersection of Kempton Road and Conestoga Drive. These surveys were conducted with an ABEM GeoSience ${ }^{1}$ computer-

controlled RAMAC system. The downhole transmitter and receiver utilized in the system are battery powered and connected to control, processing, and recording equipment at land surface by fiber-optic cables. Data are digitized down-hole and then transmitted to surfac: equipment for processing, storage, and real-time d:splay. Broad-band electric-dipole transmitting antennas with center frequencies of 22 or $60 \mathrm{MHz}$ were used.

Radar velocities were computed based on a vertical-radar-profiling (VRP) method, where a transmitting antenna is placed on the surface or in a fixed location in the borehole, and the transmitter is moved away from the receiver at specific increments. The slope of the best-fit line of the transmitter-receiver separation Flot- $^{\prime}$ ted as a function of pulse arrival time gave the ave-age velocity of radar waves in rock adjacent to the borehole.

\section{Single-Hole Directional Surveys}

Single-hole directional surveys were conducted to detect the location and orientation of fractures or f-acture zones. These surveys were conducted with a directional-receiving antenna (fig. 4) consisting of four separate loop antennas oriented orthogonally to ear $h$ other and operating at a center frequency of $60 \mathrm{MI}^{\mathrm{x}} \mathrm{Z}$. Directional information about a reflection is obtained by measuring the phase difference of the incoming wave on the different antenna elements.

The transmitter and directional receiver were lowered into the same hole with the antenna centerpoints separated by $27.9 \mathrm{ft}$. Incremental measurements every $0.82 \mathrm{ft}$ were made along the length of each well surveyed. At each measurement location, 128 complete scans were stacked (added together) to enhance signal quality. Data were processed and interpreted with ABEM software. Processing included removal of direct-current offsets, application of linear and exFonential gains, and band-pass filtering to remove highfrequency ringing caused by the difference in diameter of the radar-logging tool and well. The analysis software allows the interpretation of the strike, dip, and borehole intersection depth of planar discontinuities. The distance and direction to point-like discontinuities also can be interpreted.

\footnotetext{
${ }^{1}$ Use of firm names in this report is for identification purposes only and does not constitute endorsement by the U.S. Geological Survey.
} 

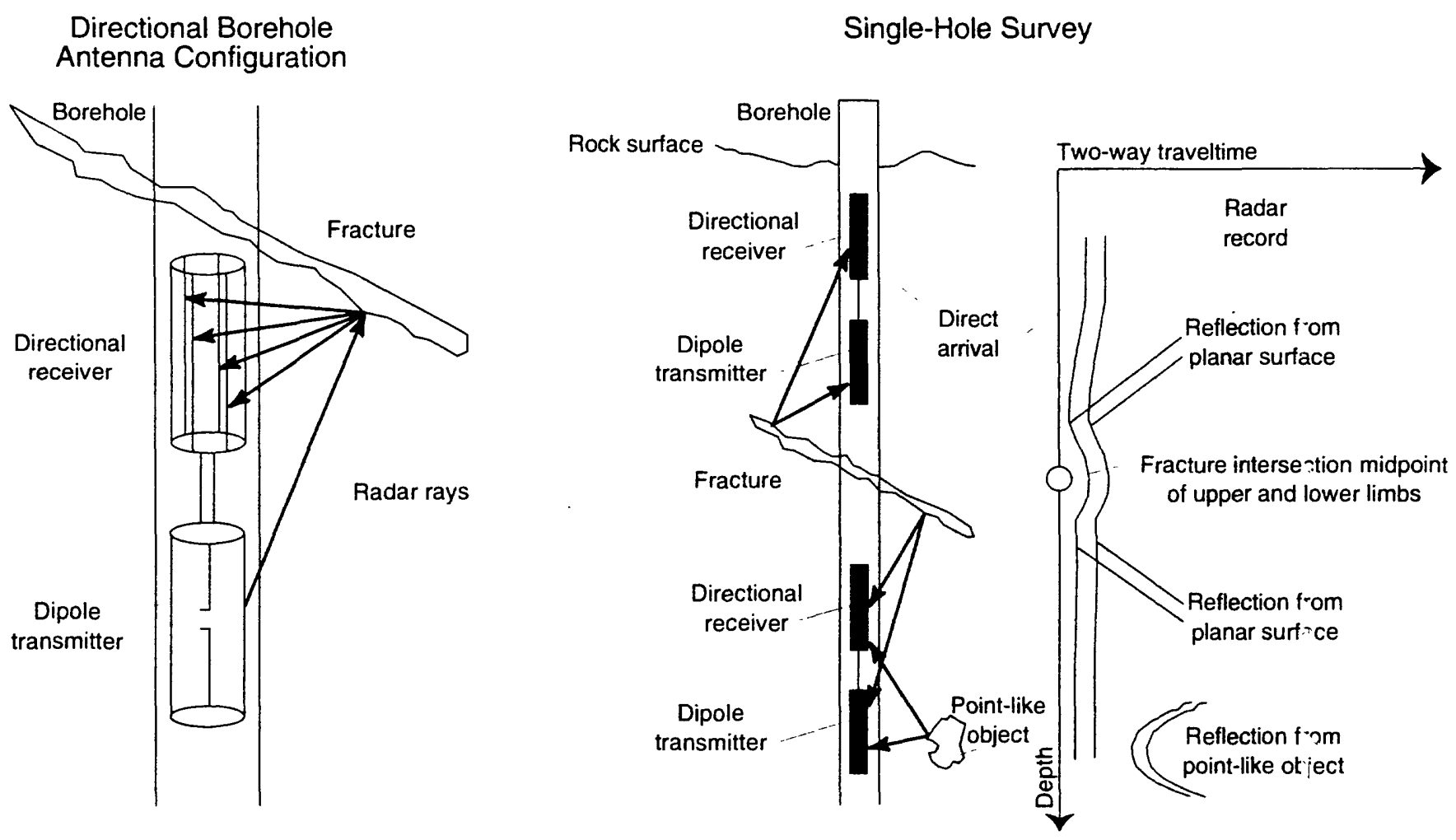

Figure 4. Directional borehole-radar antenna configuration and typical record of radar reflections received from single-hole survey.

\section{Cross-Hole Tomography Surveys}

Cross-hole tomography surveys were conducted to identify the presence of large saturated fracture zones and lithologic changes between wells. Tomography is the process by which an image of a planar section of a solid object is made. Data obtained from these surveys include the arrival time and attenuation of the radarwave pulse as it travels from the transmitter in a well to a receiver in a second well. The velocity data primarily provide information about the distribution of electromagnetic properties that are assumed to indicate electrically conductive fluids and alteration clays associated with fractures in the rock mass, and the attenuation information primarily indicates resistivity variations in the rock mass. However, the radar-velocity and attenuation data can be affected by lithologic changes in the bedrock.

A 22- $\mathrm{MHz}$ center-frequency transmitting antenna and a non-directional receiving antenna were used for these surveys. The transmitter remained stationary in one borehole while the receiver was moved in 6.56-foot increments in a second borehole. Once measurements had been made at all stations in the second well, the transmitter was moved one increment, and the process was repeated until the transmitter and receiver had occupied all possible locations. Well locaticn and borehole deviation data were used to determine the distance between the antennas at each measurement location. For interpretation, the plane between the surveyed boreholes was divided into 6.56- by 6.56-foot cells and tomographic-modeling software (Ivansson, 1984) was applied to determine the radar-wave velocit:' and radarwave attenuation in each cell. The results were smoothed to a 0.82 - by 0.82 -foot cell size with a cubicspline interpolation (Niva, 1993). Modeled radar-wave velocity and radar-wave attenuation are plotted on cross sections for visualization. The non-unique modeling results depend to some extent on the density of radarwave data points collected for a cross sectic $\eta$ and, as a result, the upper and lower corners of the tomographicplane section (where data collection density is smallest) have the least resolution. 


\section{Ground-Penetrating Radar}

The ground-penetrating radar (GPR) survey was conducted with single and dual $100-\mathrm{MHz}$ centerfrequency transmitting and receiving antennas. The antennas, mounted in fiberglass enclosures, were towed behind a four-wheel drive van, which also carried the radar electronic and recording equipment. Radar traverses were conducted on most of the roads in the study area (fig. 1). The traverses were referenced to known landmarks, which were noted on the radar records.

Selected radar records were interpreted on the basis of configuration, amplitude, continuity, and terminations of reflections. Interpretations of lithologies and structure were made by comparing the character of the reflected radar-wave configurations from the radar records to a chart of radar-wave configurations from known unconsolidated deposits (Beres and Haeni, 1991, p. 379) and interpretations of radar records from investigations of the bedrock terrain. Determination of radar-wave velocity through unconsolidated deposits was made applying equation 3 and radar record traveltime data at locations along the radar survey line where the depth to bedrock is known. Radar-wave velocity in bedrock can be determined from cross-hole borehole radar time and distance data.

\section{SURFACE AND BOREHOLE GEOPHYSICAL SURVEYS TO DETERMINE FRACTURE ORIENTATION}

Azimuthal seismic refraction, azimuthal square-array dc-resistivity, borehole radar, and groundpenetrating radar data sets are presented in this section. Sample data records and (or) graphic presentation of data are followed by observations and interpretations for each method.

\section{Azimuthal Seismic Refraction}

Azimuthal seismic-refraction field data were analyzed and interpreted to determine seismic velocity for a given line direction. Azimuthal plots of seismic velocity for three sites where azimuthal surveys were conducted are shown in figure 5 .
The seismic velocities determined with the Hobson-Overton method ranged from 9,600 to $14,332 \mathrm{ft} / \mathrm{s}$. The azimuthal seismic-velocity anisotropy (maximum velocity/minimum velocity) ranged from 1.25 at site 1 to 1.17 at site 3 . In comparison to the velocities determined with the Hobson-Overton method, velocities determined by linear regression and weighted average methods had small absolute variations and generally similar azimuthal velocity distributions. Azimuthal velocity variations from the three methods of velocity determination were used to interpret fracture strike. The graphic azimuthal plots of data indicated that:

- At site 1 , high seismic velocity was indicated from $45^{\circ}$ to $67^{\circ}$ and from $90^{\circ}$ to $112^{\circ}$. A secondary anomaly with a north-south $\left(0^{\circ}\right)$ orientation may be indicated. This velocity distribution was interpreted as primary fracture strikes of $56^{\circ}$ and $101^{\circ}$. A minor fracture set striking north-south $\left(0^{\circ}\right)$ was indicated.

- At site 2, high seismic velocity was indicated from $90^{\circ}$ to $112^{\circ}$. This was interpreted as a primary fracture strike just south of east $\left(101^{\circ}\right)$.

- At site 3, high seismic velocity was indicated trending east-northeast at about $67^{\circ}$. A small velocity increase anomaly trends north $\left(0^{\circ}\right)$. This velocity distribution was interpreted as a primary fracture orientation of east-northeast $\left(67^{\circ}\right)$ and a possible minor secondary strike orientation of north $\left(0^{\circ}\right)$.

The combined results for the area indicate a primary fracture set oriented northeast $\left(45^{\circ}\right)$ to eastsoutheast $\left(101^{\circ}\right)$ and a possible minor secondary fracture set oriented north $\left(0^{\circ}\right)$ or possibly just west of north. An alternate variation of this interpretation is that two sets of primary fractures are present-one at $56^{\circ}$ and the other at $101^{\circ}$. Because the seismic-refraction method is sensitive to seismic velocities along the refractior layer (bedrock surface), these interpreted fracture sets probably are moderate to high-angle fractures that intersect the bedrock surface. 

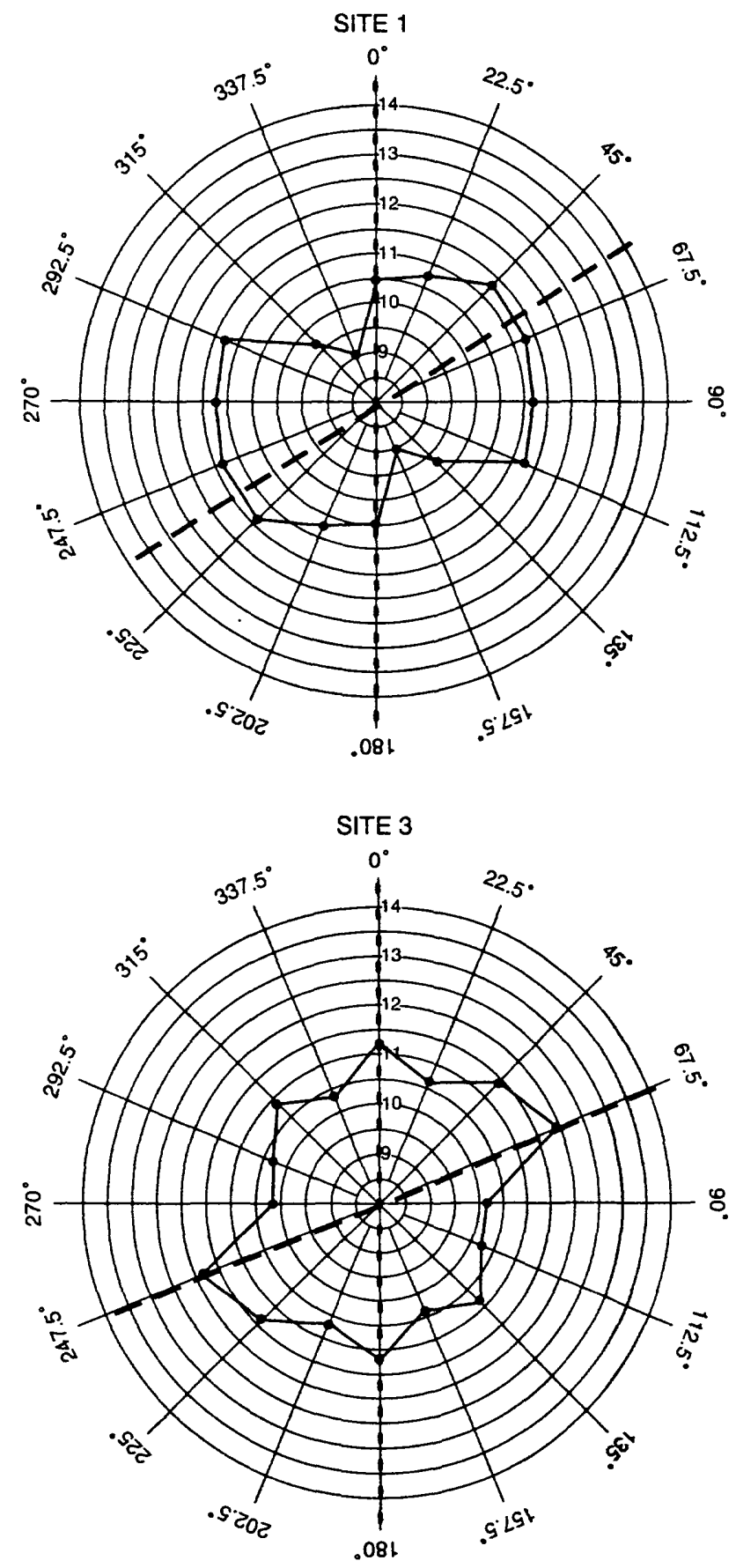

\section{Azimuthal Direct-Current Square-Array Resistivity}

Azimuthal square-array data collected at the three sites (fig. 1) indicated variations in apparent resistivity with measurement direction. At each site, these variations changed as the size of the array increased. At small array spacings, resistivity anomalies (resistivity highs with corresponding orthogonal resistivity lows) were small and

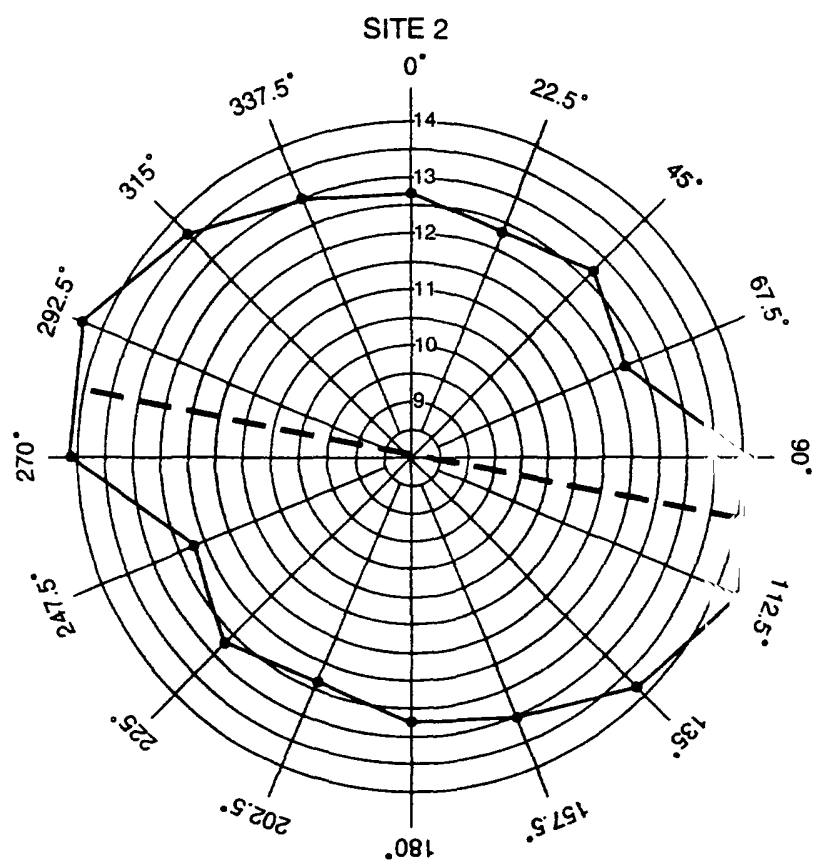

EXPLANATION

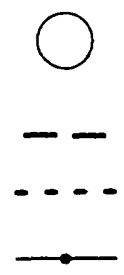

LINE OF EQUAL SEISMIC VELOCITY, IN KILOFEET PER SECOND

INTERPRETED PRIMARY FRACTURE STRIKE

INTERPRETED SECONDARY FRACTURE STRIKE

DATA POINTS SHOWING INTERPRETED S IISMIC VELOCITY THROUGH BEDROCK AT INDICATED AZIMUTHAL DIRECTIONS

Figure 5. Azimuthal plots of seismic velocity in be trock determined with the Hobson-Overton method of valocity analysis, sites 1-3, Uxbridge, Massachusetts.

randomly distributed. This probably was the result of lithologic heterogeneities in the unconsolidated surficial deposits obscuring the effect of bedrock fracture on resistivity at this scale and (or) bedrock fracturing that is not well developed at this scale. Resistivity data from the larger array spacings were used to interpret fracture characteristics. Azimuthal plots of resistivity data fo- sites 1-3 at array spacings of 112,56 , and $98 \mathrm{ft}$, respectively, are 

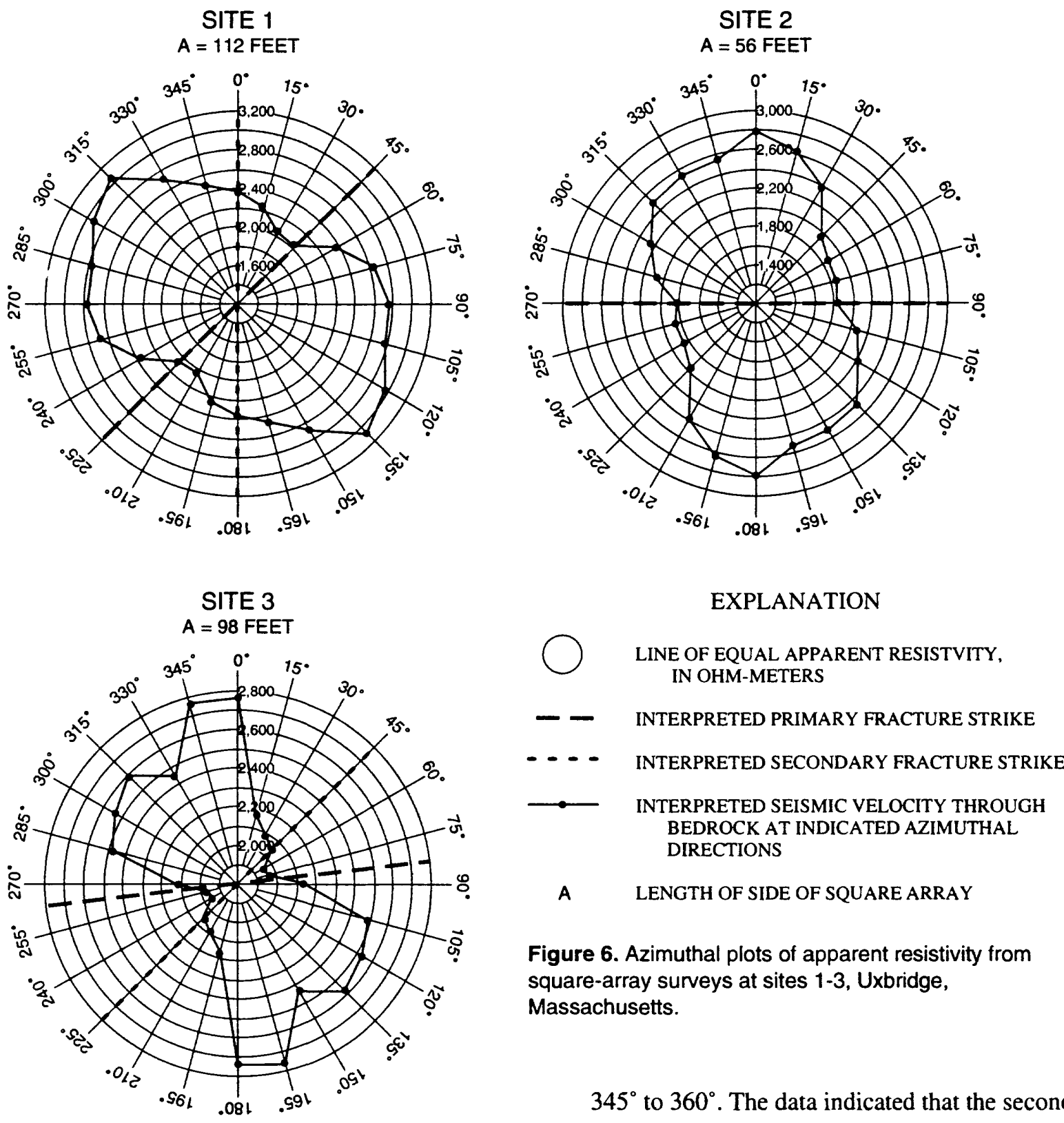

\section{A LENGTH OF SIDE OF SQUARE ARRAY}

Figure 6. Azimuthal plots of apparent resistivity from square-array surveys at sites 1-3, Uxbridge, Massachusetts.

shown in figure 6. Data from other array spacings were used for analysis and are discussed as necessary. The graphical plots of resistivity data indicated that:

- At site 1 , a primary resistivity high (anomaly) at $135^{\circ}$ $\left(135^{\circ}\right.$ and $315^{\circ}$ ) with a corresponding orthogonal resistivity low at $45^{\circ}$ was present. A secondary anomaly at $90^{\circ}$ was evident in data from the 59- and 66-foot arrays, but less pronounced in the 79- and 112-foot arrays. These anomalies were interpreted as a primary fracture orientation of $45^{\circ}$ and a possible secondary set from $345^{\circ}$ to $360^{\circ}$. The data indicated that the secondary fracture set was present at shallow bedrock depth but may not be pervasive at depth.

- At site 2 , a primary resistivity anomaly oriented north $\left(0^{\circ}\right)$ was interpreted to indicate a primary fracture orientation of east $\left(90^{\circ}\right)$.

- At site 3, a primary resistivity anomaly was from $165^{\circ}$ to $180^{\circ}$. A secondary anomaly at $135^{\circ}$ was evident from the 65-, 82-, and 98-foot $A$-spacing data. These anomalies were interpreted as a primary fracture set frc $775^{\circ}$ to $90^{\circ}$ and a secondary fracture set at $45^{\circ}$. 
Fracture strike also was determined analytically from the resistivity data using the cross-squares method (Habberjam, 1975). Results from this method indicated a primary fracture strike at sites $1-3$, of $61^{\circ} .79^{\circ}$, and $92^{\circ}$, which was consistent with the primary-fracture strike directions determined from the azimuthal plots.

\section{Borehole Radar}

This section presents the results of the single-hole directional and cross-hole tomography borehole-radar surveys that were conducted in three wells.

\section{Single-Hole Directional Surveys}

Fifty-two radar reflections were identified on directional radar records from three wells. Radar reflections were interpreted as 46 individual fractures or fracture zones and two point reflectors that may represent the intersection of several fractures. One of the dirctional radar records from well KR30 and the interpreted location of radar reflectors (fractures) on that record are shown in figure 7. It was determined that fractures were detected as far as $147 \mathrm{ft}$ from the wells on the basis of equation 3, a measured radar-wave velocity of $0.37 \mathrm{ft} / \mathrm{ns}$, and traveltime data from the radar records. Relative dielectric permittivity of the bedrock was determined to be 7.01 using the measured radar-wave velocity and equation 4 . This dielectric permittivity is indicative of wet granite (tat'e 1) and supports the assumption that the fractures were water filled. The resolution of the radar records is 2 to $3 \mathrm{ft}$ based on a calculated radar wavelength of $6.16 \mathrm{ft}$ (eq. 5, p. 22) and the observations of Trabant (1984). Applyirg the average radar-wave velocity and data from the radar records, the location and orientation of each of the fractures were determined. Fractures interpreted from the single-hole directional records are listed in table 2 .

\section{RADAR RECORD}

\section{INTERPRETED RECORD}

TWO-WAY TRAVELTIME, IN MICROSECONDS
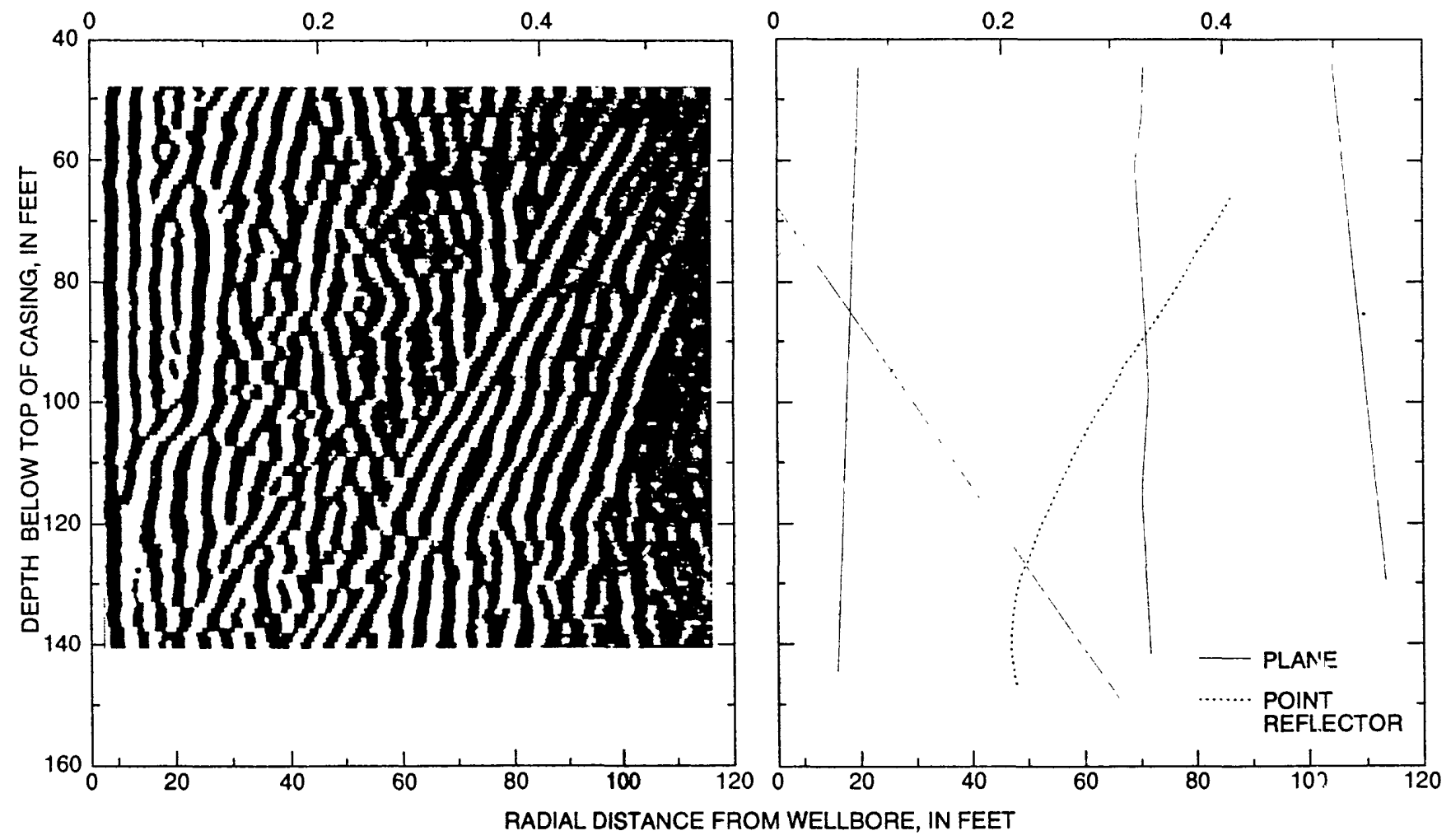

Figure 7. Borehole-radar record and interpreted location of reflectors from well KR30, Uxbridge, Massachusetts. 
Table 2. Radar reflectors identified in single-hole directional radar surveys of wells KR29, KR30, and KR30A, Uxbridge, Massachusetts

[ft, foot. ?, signal too weak to determine; NA, not applicable to angular reflectors; --, no strike and (or) dip data. Shading means reflectors identified in multiple wells]

\begin{tabular}{|c|c|c|c|c|c|c|c|c|c|}
\hline $\begin{array}{l}\text { Reflector } \\
\text { type and } \\
\text { designation }\end{array}$ & $\begin{array}{l}\text { Depth that } \\
\text { reflector } \\
\text { intersects } \\
\text { well } \\
\text { (ft) }\end{array}$ & $\begin{array}{c}\text { Horizontal } \\
\text { distance } \\
\text { from well } \\
\text { (ft) }\end{array}$ & $\begin{array}{c}\text { Strike } \\
\text { (true north } \\
\text { degrees) }\end{array}$ & $\begin{array}{c}\text { Dip } \\
\text { (degrees) }\end{array}$ & $\begin{array}{l}\text { Reflector } \\
\text { type and } \\
\text { designation }\end{array}$ & $\begin{array}{l}\text { Depth that } \\
\text { reflector } \\
\text { intersects } \\
\text { well } \\
\text { (ft) }\end{array}$ & $\begin{array}{c}\text { Horizontal } \\
\text { distance } \\
\text { from well } \\
\text { (ft) }\end{array}$ & $\begin{array}{c}\text { Strike } \\
\text { (true north } \\
\text { degrees) }\end{array}$ & $\begin{array}{c}\text { Dip } \\
\text { (denrees) }\end{array}$ \\
\hline \multicolumn{5}{|c|}{ WELL KR29 } & Plane 14 & 224 & NA & 275 & 29 \\
\hline Plane 1 & $1-438$ & NA & 75 & 82 & Plane $15^{4}$ & 230 & NA & 75 & 57 \\
\hline Plane 2 & 115 & NA & 115 & 55 & Plane $16^{2}$ & Does not & 3101 & 345 & Nrar \\
\hline Plane 3 & 134 & NA & 325 & 61 & 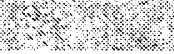 & Interseet & (west) & & Vertical \\
\hline Plane 4 & 138 & NA & 245 & 14 & Plane 17 & 305 & NA & 185 & 52 \\
\hline Plane 5 & 159 & NA & $?$ & 32 & Plane 18 & 369 & NA & 75 & 69 \\
\hline Plane 6 & 183 & NA & 105 & 61 & \multicolumn{5}{|c|}{ WELL KR30A } \\
\hline Plane 7 & 192 & NA & 35 & 38 & \multirow{2}{*}{\multicolumn{2}{|c|}{ Plane 1 ${ }^{2}$ Does not }} & 359 (east) & 345 & Near \\
\hline Plane 8 & 218 & NA & 25 & 62 & & & & & vertical \\
\hline Plane 9 & 231 & NA & 75 & 54 & Plane 2 & $1-8$ & $\mathrm{NA}$ & 255 & 70 \\
\hline Plane 10 & 247 & NA & $?$ & 59 & Plane 3 & 12 & NA & 295 & 54 \\
\hline Plane 11 & 305 & NA & 125 & 47 & Plane 4 & 37 & NA & 75 & 39 \\
\hline Plane 12 & 1,820 & NA & 115 & 90 & Plane 5 & 37 & NA & 75 & 68 \\
\hline Plane $13^{2}$ & Does not & $3_{43}$ (west) & 165 & 89 & Plane $6^{4}$ & 60 & NA & 265 & 46 \\
\hline & intersect & & 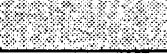 & 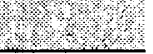 & Point A & 5110 & $332\left(275^{\circ}\right)$ & - & -- \\
\hline \multicolumn{5}{|c|}{ WELL KR30 } & Plane 7 & 128 & NA & 355 & 42 \\
\hline Plane 1 & $1-1,308$ & NA & 165 & 87 & Plane $8^{4}$ & 151 & $\mathrm{NA}$ & 75 & 56 \\
\hline Plane 2 & $1-970$ & NA & 225 & 83 & Plane 9 & 170 & NA & 25 & 57 \\
\hline Plane 3 & ${ }^{1}-220$ & NA & 115 & 67 & Plane 10 & 194 & NA & 75 & 56 \\
\hline Plane 4 & 1.89 & NA & 115 & 54 & Plane 11 & 218 & NA & 65 & 49 \\
\hline Plane 5 & $1-52$ & NA & 295 & 54 & Plane 12 & 236 & NA & 295 & 57 \\
\hline Plane 6 & $1-50$ & NA & 255 & 70 & Plane 13 & 275 & NA & 75 & 57 \\
\hline Plane 7 & $1-15$ & NA & 275 & 49 & Plane 14 & 296 & NA & 335 & 30 \\
\hline Plane $8^{4}$ & 23 & NA & 265 & 42. & Plane 15 & 315 & NA & 325 & 57 \\
\hline Plane 9 & 65 & $\mathrm{NA}$ & 255 & 26 & Plane 16 & 380 & NA & 265 & 36 \\
\hline Plane 10 & 101 & NA & 65 & 48 & Plane 17 & 381 & NA & 95 & 50 \\
\hline Plane 11 & 139 & NA & 255 & 44 & Plane 18 & 394 & NA & $?$ & 60 \\
\hline Point A & ${ }^{5} 149$ & ${ }^{3} 59\left(185^{\circ}\right)$ & -- & -- & Plane 19 & 419 & NA & 25 & 79 \\
\hline Plane 12 & 162 & NA & 175 & 34 & & & & & \\
\hline Plane 13 & 175 & NA & 245 & 45 & & & & & \\
\hline
\end{tabular}

${ }^{\mathrm{I}}$ Negative number indicates intersection of radar reflector plane and projection of well above land surface.

2 Vertical reflector identified on the radar record of all three wells.

${ }^{3}$ Azimuth from well to point reflector, or vertical plane.

${ }^{4}$ Reflectors identified on radar records from wells KR30 and KR30A.

${ }^{5}$ Vertical distance from top of well to point reflector. 


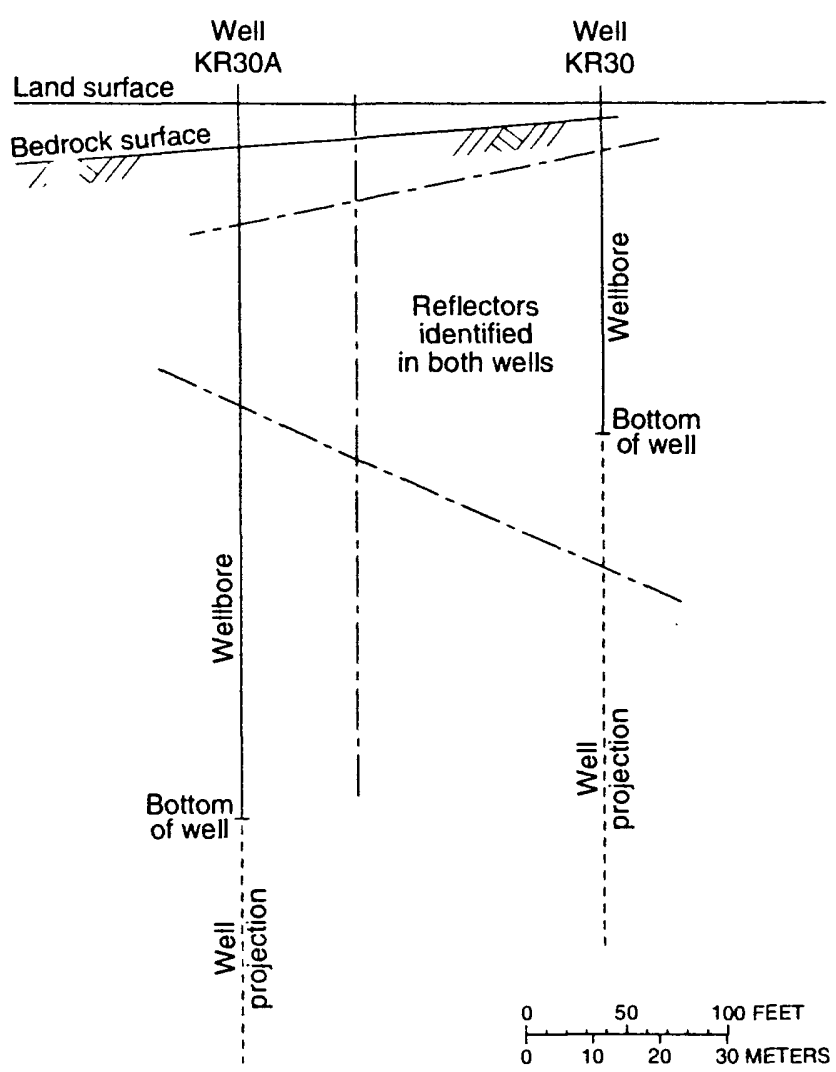

Figure 8. Common reflectors identified in single-hole radar survey in wells KR30 and KR30A, Uxbridge, Massachusetts.

The relatively short distance ( $125 \mathrm{ft}$ ) between wells KR30 and KR30A (fig.1) allowed for correlation of individual fractures between these wells. Three common fractures were identified in the records of both wells (table 2 and fig. 8). One vertical fracture was detected in data sets from all three wells surveyed. This fracture, striking $345^{\circ}$, does not intersect any of the wells (fig. 9) and may be related to northwest-striking faulting in the area (Zen and others, 1983).

\section{Cross-Hole Tomography Surveys}

Radar-wave velocity and radar-wave attenuation tomograms were prepared from data collected during cross-hole radar surveys between well pairs KR29-KR30 and KR30-KR30A. Both tomograms indicated a similar pattern of low-velocity/high-attenuation zones. Radarwave attenuation tomograms for the sections between wells KR29-KR30 and KR30A-KR30 are shown in figure 10 . The low velocity/high attenuation zone was interpreted as a planar fracture zone striking $\mathrm{N} 63^{\circ} \mathrm{W}$ and dipping $55^{\circ} \mathrm{S}$. Borehole-geophysical logs of the surveyed

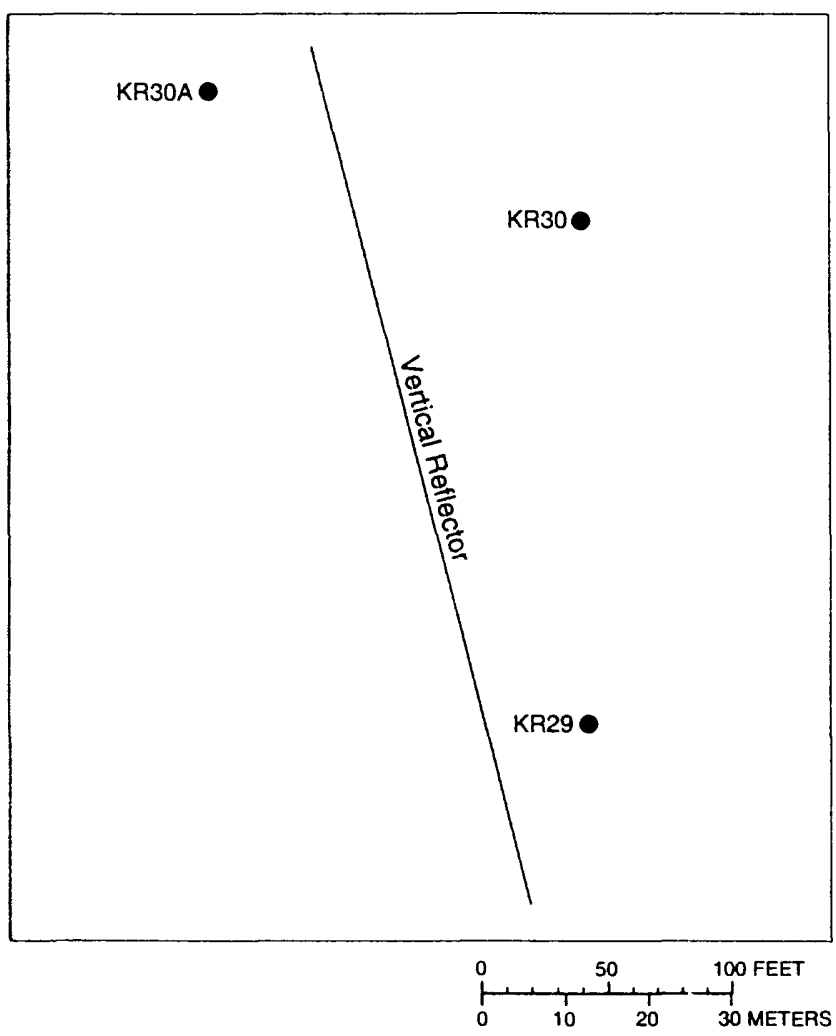

\section{EXPLANATION}

KR29 BEDROCK WELLS WHERE BOREHOLE-RADAR SURVEYS WERE CONDUCTED--Number is local well number assigned by the Massachusetts Department of Environmenta' Protection

Figure 9. Location of common vertical reflector identified in single-hole radar survey in wells KR29, KR30, an $\mathrm{KR} 30 \mathrm{~A}$ in Uxbridge, Massachusetts.

wells indicated low resistivity and high self-potential anomalies at depths where this feature intersects the wells. Interpretation of borehole-video logs of the three wells indicated that this feature is related to increasec amounts of amphibolite in wells KR29 and KR30 but not in well KR30A. Borehole-flowmeter logging (Paillet and Ollilia, 1994) indicated a permeable fracture at about $6 \varepsilon \mathrm{ft}$ in well KR30; resistivity, spontaneous potential, and fluid-conductivity-log anomalies indicate fractures and fluid movement at about $178 \mathrm{ft}$ in well KR30A (B.P. Hansen, U.S. Geological Survey, written commun., 1994). Plots of direct-radar-arrival pulse amplitude and arrival time from single-hole surveys (Niva, 1993) indicated a decreased pulse amplitude and delayed radar-arrival time in this zone. These findings were consistent with the interpretation of a planar fracture zone between the three wells. 


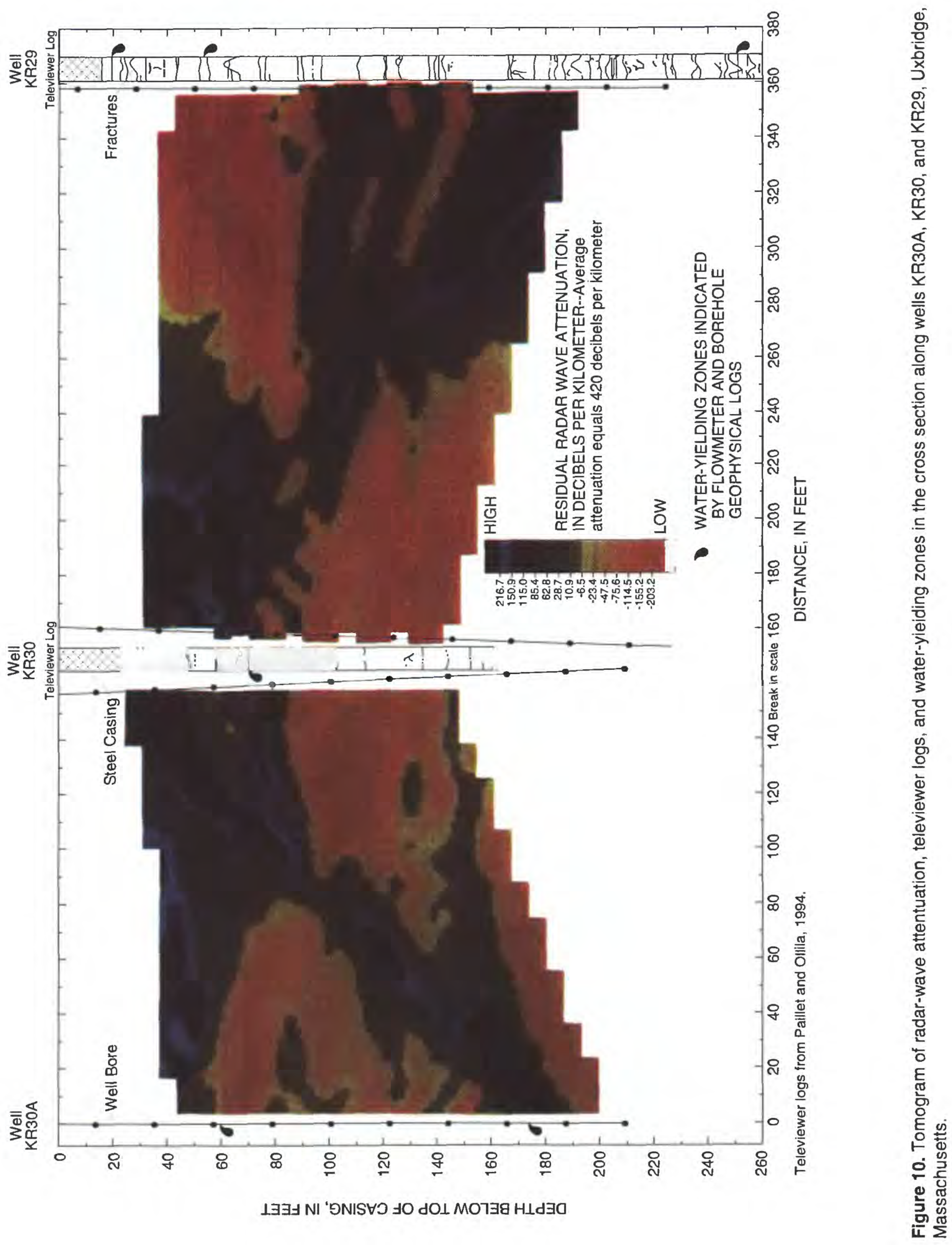




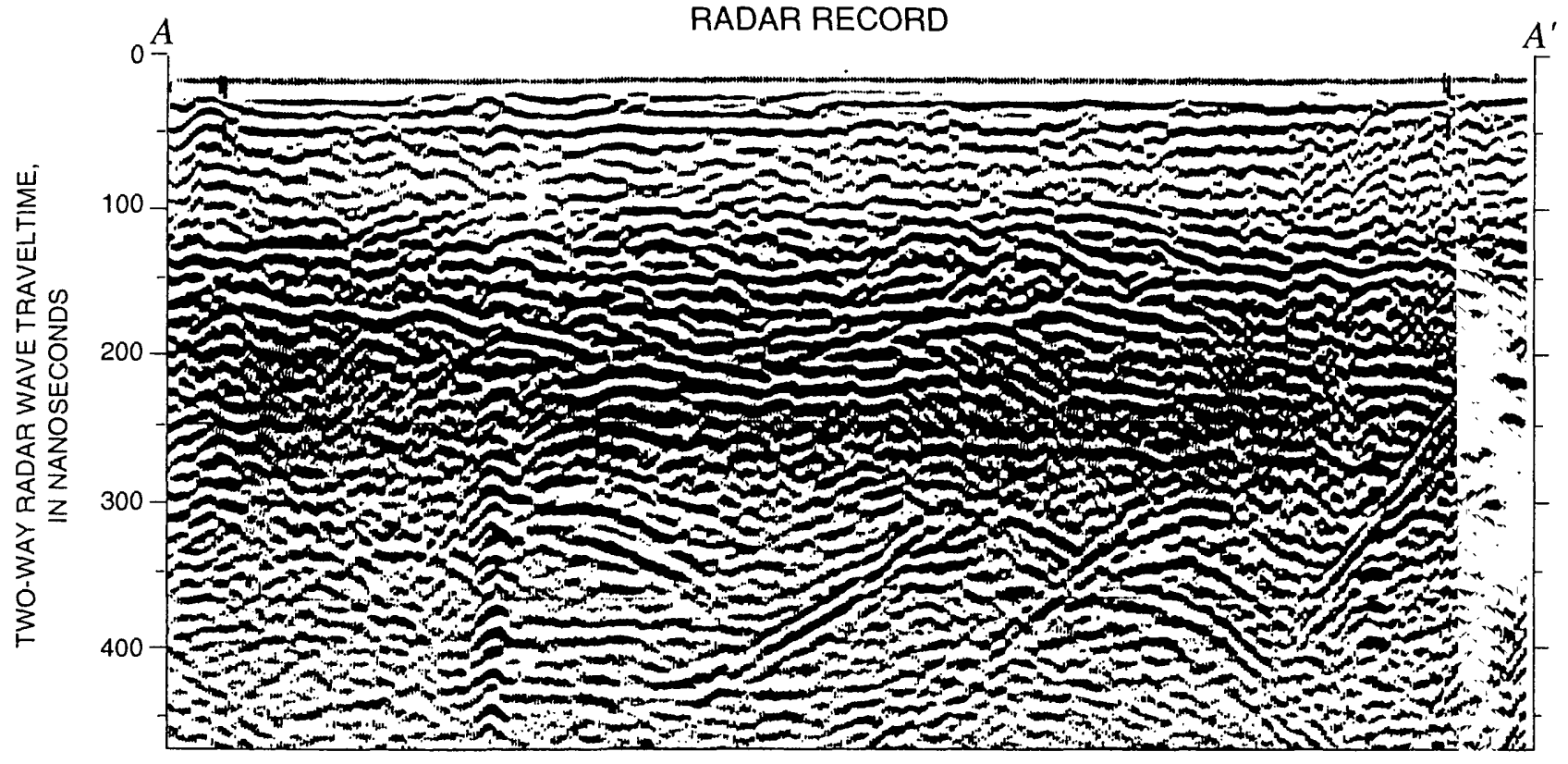

INTERPRETED GEOLOGIC CROSS SECTION

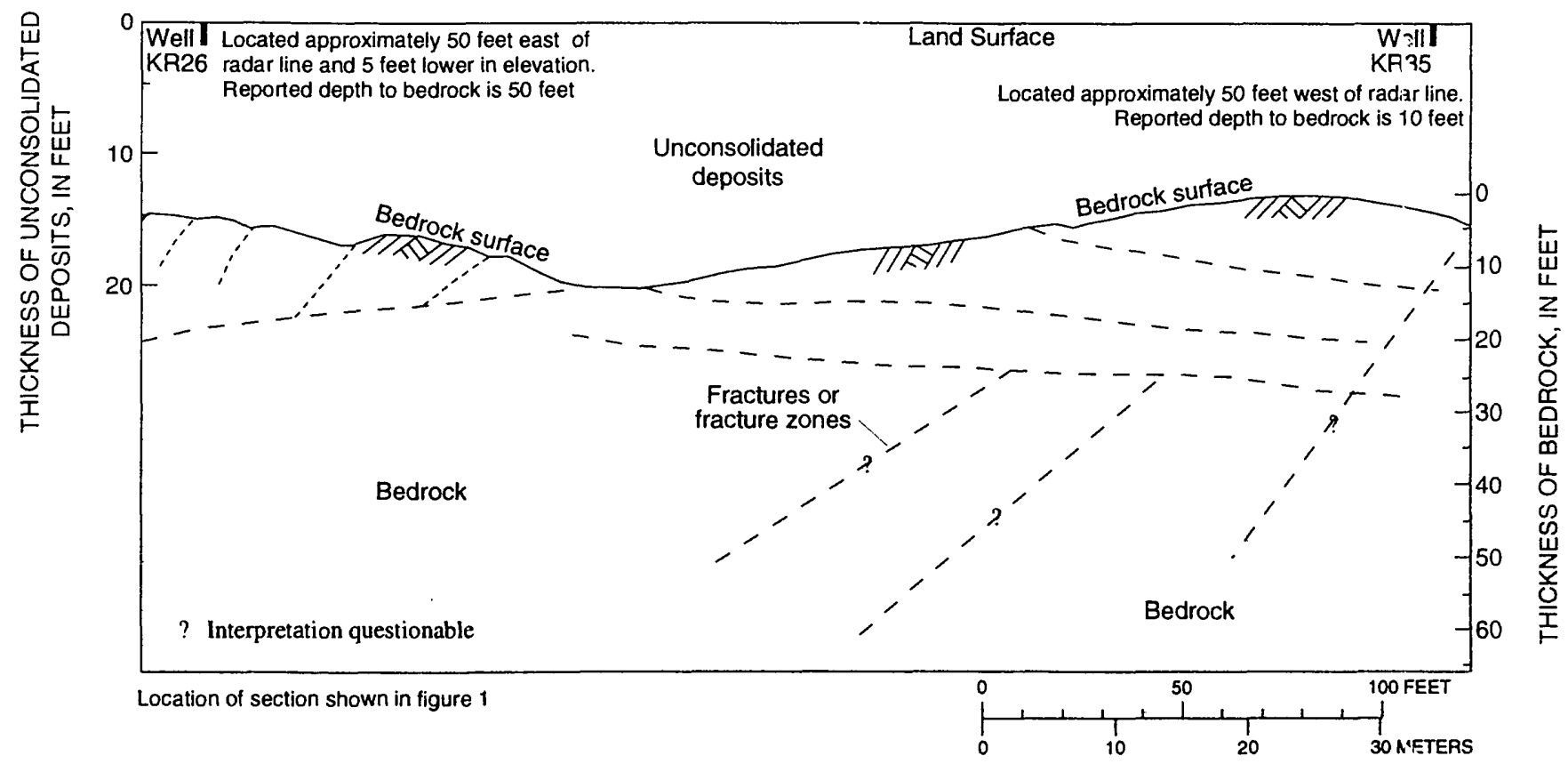

APPROXIMATE VERTICAL EXAGGERATION $\times 2.2$

Figure 11. One hundred-Megahertz ground-penetrating radar record and interpreted geologic cross section $A-A^{\prime}$ along Conestoga Drive, Uxbridge, Massachusetts. 


\section{Ground-Penetrating Radar}

The $100-\mathrm{MHz}$ GPR surveys were mostly conducted along roads (fig. 1). An example of a radar record and interpreted cross section is shown in figure 11. For unconsolidated deposits, an average radar-wave velocity of $0.2 \mathrm{ft} / \mathrm{ns}$ was used for radar-record interpretation and determined based on equation 3 at six locations along the radar lines where depth-tobedrock data were available. For bedrock, a radar-wave velocity of $0.37 \mathrm{ft} / \mathrm{ns}$ was determined from the cross-hole radar data. There also may be a different radar-wave velocity in saturated and unsaturated unconsolidated deposits: however, it was not possible to determine any difference from the available data. Because of the different radarwave velocities, radar records and interpreted GPR cross sections shown in this report have two depth scales, one for unconsolidated deposits and one for bedrock. The resolution of the $100-\mathrm{MHz}$ GPR records is about 0.7 to $1.0 \mathrm{ft}$ for unconsolidated deposits and 1.2 to $1.8 \mathrm{ft}$ for bedrock. A dielectric permittivity of 24 , determined for the unconsolidated deposits based on equation 4 , is indicative of a silty sand (table 1), which is similar to the unconsolidated material reported on several drilling logs available for the area. Examination of the GPR record indicates a maximum radar-wave penetration of $50 \mathrm{ft}$ for unconsolidated depos-

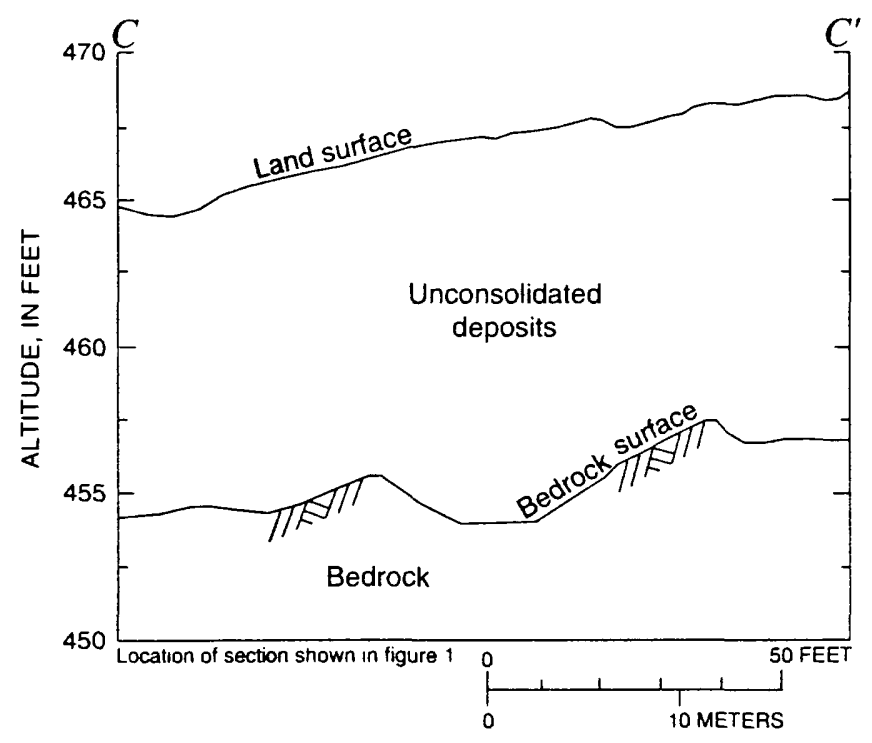

Figure 12. Geologic section $C$ - $C$ ' interpreted from seismicrefraction survey data at site 1 on Conestoga Drive, Uxbridge, Massachusetts. its and 100 to $150 \mathrm{ft}$ for bedrock. Maximum bedrock penetration occurs where the bedrock surface is at or near land surface. Horizontal and subhorizontal reflectors similar to those shown in figure 12 are interpreted as horizontal and subhorizontal fractures or fracture zones. These fractures are visible on the radar record at numerous locations

\section{Correlation of Fracture Orientation Results}

An east-northeast trending fracture set or zone was interpreted from the seismic-refraction, square-array resistivity, and directional borehole-radar data. Most of th ${ }^{\text {a }}$ interpreted fracture azimuths from the seismic-refraction and square-array resistivity interpretations were between $55^{\circ}$ and $101^{\circ}$ (table 3). The borehole-radar data indicated that the fractures that are continuous between surveyed wells had a east-northeast $\left(80^{\circ}\right)$ trend. A weaker correlation between data sets may indicate a secondary northtrending fracture set or zone. The primary and secon tary fracture orientations were consistent with previous outcrop fracture mapping in the area (Paillet and Ollila, 1994) and indicated that the fracture orientation observed at land surface was pervasive at depth.

The primary northeast to east fracture strike observed in the geophysical data may be related to the east-northeast regional stress maximum (Nataraja, 1977; Lee and L:ohl, 1989). Fracturing striking parallel to the regional stress direction tends to have larger aperture openings thar fractures orthogonal to the regional stress direction, which tend to be forced closed.

Table 3. Primary and secondary fracture-strike orientations determined from azimuthal seismic-refraction and azimuthal square-array resistivity surveys, Uxbridge, Massachusetts

[All data except Site No. are in degrees relative to true north]

\begin{tabular}{|c|c|c|c|c|c|}
\hline \multirow{3}{*}{$\begin{array}{l}\text { Site } \\
\text { No. }\end{array}$} & \multicolumn{3}{|c|}{ Primary fracture orientation } & \multicolumn{2}{|c|}{$\begin{array}{c}\text { Secondary fracture } \\
\text { orientation }\end{array}$} \\
\hline & \multirow{2}{*}{$\begin{array}{l}\text { Seismic } \\
\text { data }\end{array}$} & \multicolumn{2}{|c|}{ Resistivity data } & \multirow{2}{*}{ Seismic } & \multirow{2}{*}{ Resistivity } \\
\hline & & Graphic & Analytical & & \\
\hline 1 & 55 and 101 & 45 & 61 & 0 & 350 \\
\hline 2 & 101 & 90 & 79 & none & none \\
\hline 3 & 67 & $75-90$ & 92 & 0 & 45 \\
\hline
\end{tabular}




\section{OTHER SITE CHARACTERISTICS DETERMINED FROM GEOPHYSICAL SURVEYS}

Geophysical surveys are commonly conducted to provide information about a particular characteristic of a study area. Frequently, these surveys also provide additional information that can be used for site characterization. This section presents fracture porosity and depth to bedrock information determined from the geophysical data that can be utilized for site characterization.

\section{Fracture Porosity and Aperture}

Apparent square-array resistivity data can be used to estimate secondary porosity and average fracture aperture of the high-angle fractures that cause the azimuthal variations (anisotropy) in resistivity. Fracture characteristics determined from the squarearray resistivity data are summarized in table 4. Porosity ranged from 0.0042 to 0.0047 and average fracture aperture ranged from 0.0067 to $0.0073 \mathrm{ft}$. This porosity was not the total secondary porosity of the bedrock but was only associated with the high-angle fractures. Numerical descriptions from table 4 should be considered as maximum possible values of high-

Table 4. Average high-angle bedrock fracture characteristics determined from square-array resistivity survey data from sites 1-3, Uxbridge, Massachusetts

Average fracture aperture: based on fracture spacing of 0.64 fractures per foot. determined by fracture mapping on north-south bedrock outerops on Route 122 and Conestoga Drive. Uxbridge, Mass. Primary fracture strike given in degrees relative to true northl

\begin{tabular}{cccccc}
\hline $\begin{array}{c}\text { Site } \\
\text { No. }\end{array}$ & $\begin{array}{c}\text { Square- } \\
\text { array size } \\
\text { (feet) }\end{array}$ & $\begin{array}{c}\text { Resistivity } \\
\text { anisotropy }\end{array}$ & $\begin{array}{c}\text { Primary } \\
\text { fracture } \\
\text { strike }\end{array}$ & $\begin{array}{c}\text { Fracture } \\
\text { porosity }\end{array}$ & $\begin{array}{c}\text { Average } \\
\text { fracture } \\
\text { aperture } \\
\text { (feet) }\end{array}$ \\
\hline 1 & 112 & 1.11 & 61 & 0.0042 & 0.0073 \\
2 & 56 & 1.12 & 79 & .0043 & .0067 \\
3 & 98 & 1.10 & 92 & .0047 & .0073 \\
\hline
\end{tabular}

angle fractures. The resistivity data used to make the determinations may include the effects of frasture mineralization and bedrock alteration associc ${ }^{+}$ed with fracturing which, if present, would decrease porosity and effective aperture. Also, the method used to determine porosity of high-angle fractures does not account for the additional porosity associated with horizontal or low-angle fractures that are present.

\section{Depth to Bedrock}

Two geophysical methods used in this study provided depth to bedrock information. Azimuthal seismic-refraction data can be utilized to delineate a detailed configuration of the bedrock surface. A northsouth cross section for site 1 (fig. 1) is showr in figure 13 . Because of the relatively small spacing $(5 \mathrm{ft})$ between geophones and many shot points (five) used for these surveys, the resulting high-resolution cross sections indicated small changes in the bedrock-surface elevation.

The bedrock surface also was indicated by radarwave reflections on the $100-\mathrm{MHz}$ GPR records. In general, a depth to bedrock ranging from 0 to $20 \mathrm{ft}$ below land surface was indicated along most of the surveyed lines with good correlation with well data along the lines. One exception, located along Conestoga Drive and shown in figure 13, had a maximum indirated depth to bedrock of 45 to $50 \mathrm{ft}$ below land surface. This interpretation was supported by a reported depth to bedrock of $50 \mathrm{ft}$ on the drilling log of an adjarent well. This depression in the bedrock surface probably is part of a buried bedrock channel that could be a pathway or sink for locally present contamination that could move along the bedrock surface. The configuration, orientation, and extent of this channel presently (19?5) is unknown. 


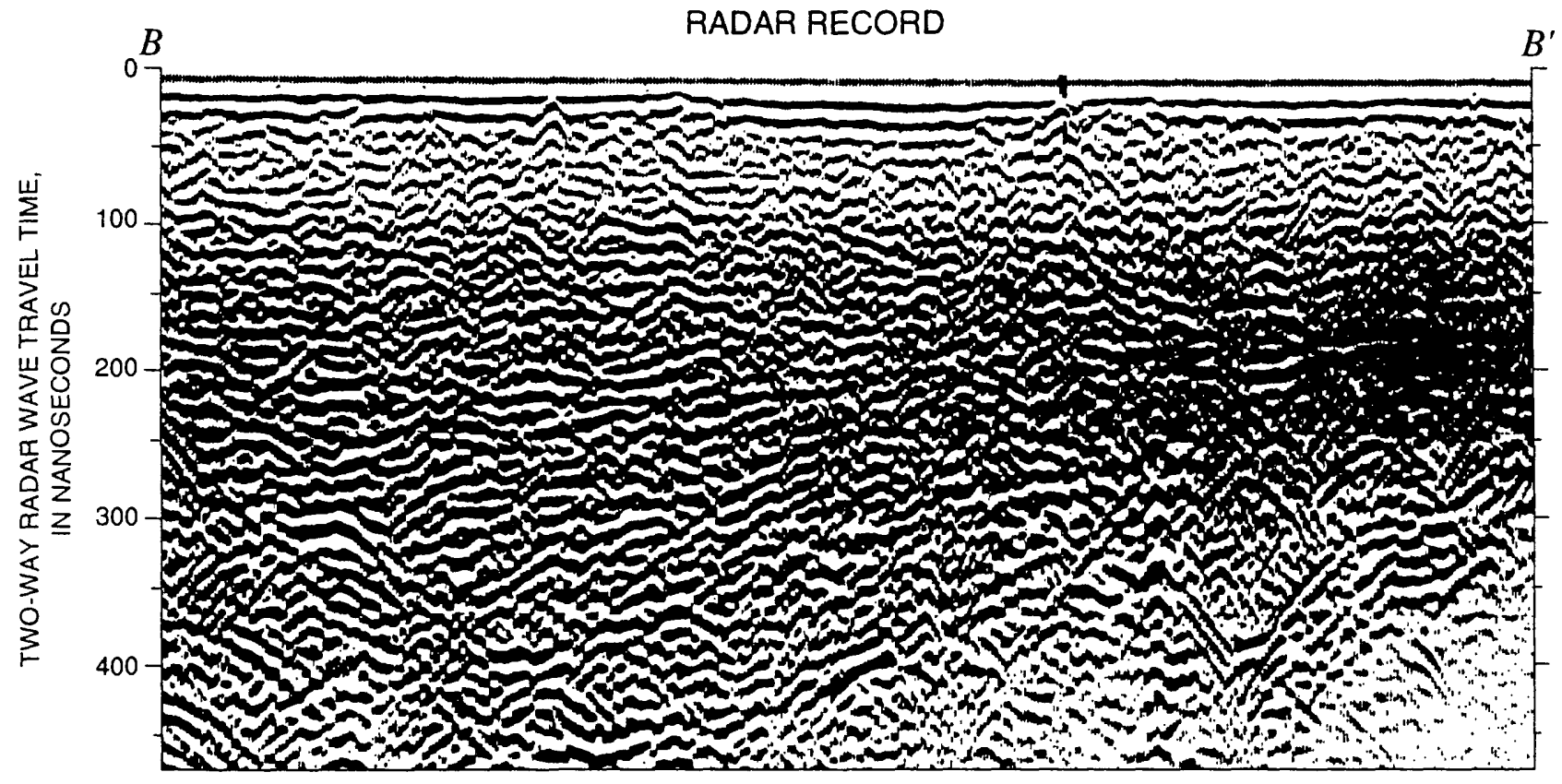

\section{INTERPRETED GEOLOGIC CROSS SECTION}

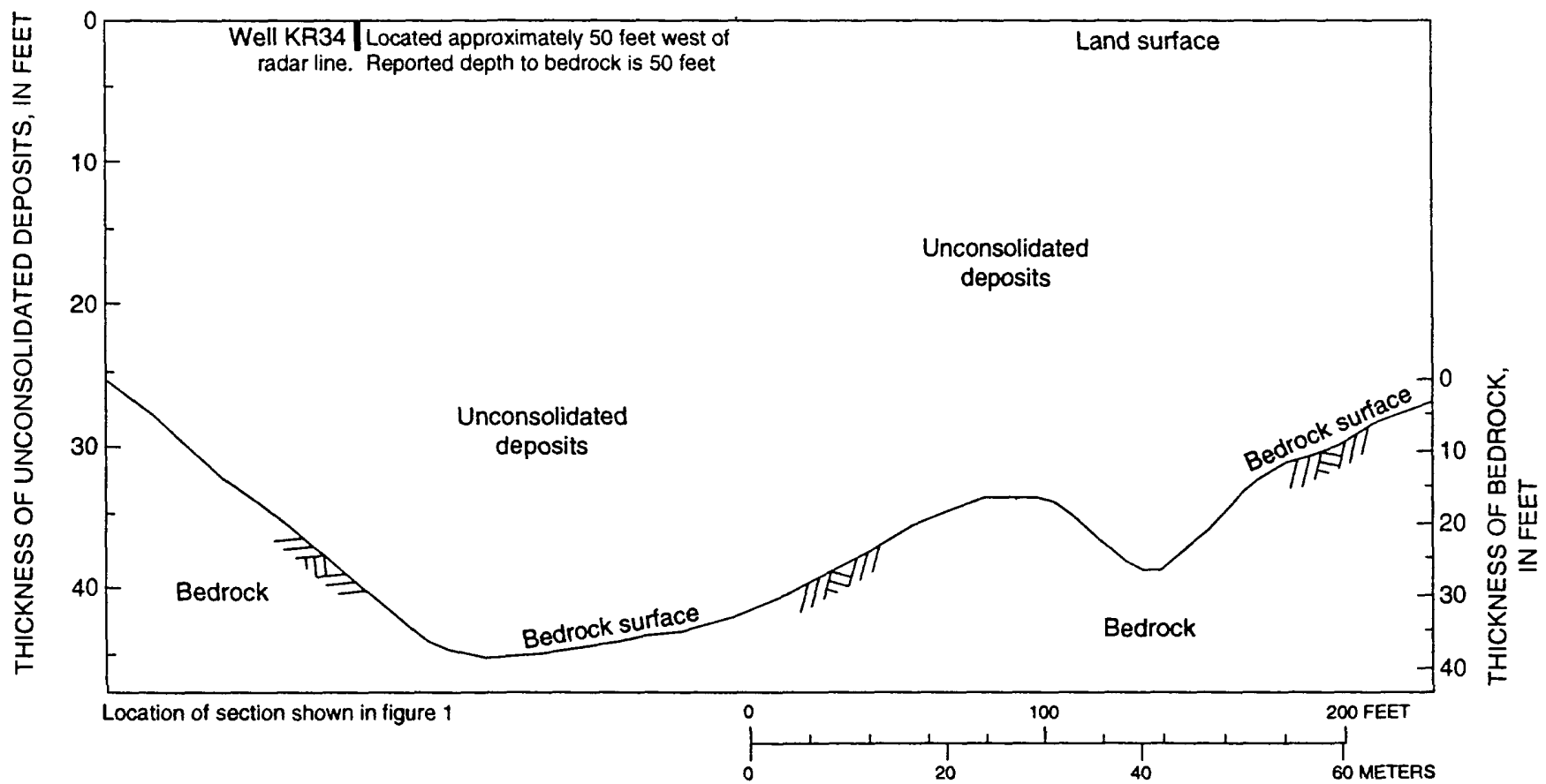

APPROXIMATE VERTICAL EXAGGERATION $\times 3.4$

Figure 13. One hundred-Megahertz ground-penetrating radar record and interpreted geologic cross section $B$ - $B^{\prime}$ along Conestoga Drive, Uxbridge, Massachusetts. 


\section{SUMMARY AND CONCLUSIONS}

A study using four geophysical survey methods was conducted to determine bedrock fracture orientation and other site characteristics that can be used to determine ground-water movement and contaminant transport at a fractured crystalline bedrock site in Millville and Uxbridge, Massachusetts.

Azimuthal seismic-refraction and azimuthal squarearray dc-resistivity surveys were conducted at three sites. Borehole-radar surveys were conducted in a cluster of three wells and GPR surveys were conducted along roads in the study area.

Azimuthal seismic-refraction data indicated a primary fracture strike from $56^{\circ}$ to $101^{\circ}$ at site $1,101^{\circ}$ at site 2 , and $67^{\circ}$ at site 3 . Analysis of the data suggests a secondary fracture strike orientation of $0^{\circ}$ at sites 1 and 2. A<imuthal square-array resistivity data indicates primlary high-angle fractures with a $45^{\circ}$ strike at site 1 , $90^{\circ}$ at site 2 , and from $75^{\circ}$ to $90^{\circ}$ at site 3 . Secondary fracturing from $345^{\circ}$ to $0^{\circ}$ at site 1 and $45^{\circ}$ at site 3 is suggested.

Directional borehole-radar data from three wells indicated 46 fractures or fracture zones. Fractures were detected from as far as $147 \mathrm{ft}$ from the surveyed wells. Two fractures with east-west strikes and moderate dip were observed on the radar records of two wells. One vertical fracture was detected on the radar records from all three wells surveyed. Interpretation of cross-hole borehole-radar data from surveys between two pairs of wells showed patterns of low velocity and high attenuation of radar waves. This high velocity/high attenuation zone was interpreted as a planar fracture zone striking $\mathrm{N} .63^{\circ} \mathrm{W}$. and dipping $55^{\circ} \mathrm{S}$.

Maximum depth of GPR penetration of bedrock was 100 to $150 \mathrm{ft}$ where bedrock was at or near land surface. Radar reflectors were interpreted as horizontal and subhorizontal fractures at numerous locations.

Correlation of the azimuthal seismic-refraction, azimuthal square-array resistivity, and directional borehole-radar data indicated good agreement between data sets and, in general, indicated primary high-angle fracturing striking east-northeast $\left(80^{\circ}\right)$. Secondary fracturing, trending north $\left(0^{\circ}\right)$, was weakly indicated. Some variation in fracture strike may be present at the three sites. Primary and secondary fracture strikes were consistent with previous fracture mapping on outcrops. The data also indicated that the indicated fracturing was pervasive at depth.

The primary northeast to east fracture strike indicated by the geophysical data may be related to the eastnortheast regional stress maximum. Fracturing striking parallel to the regional stress direction tends to have larger aperture openings than fractures orthogonal to the regional stress direction, which tend to be forced closed.

Approximate maximum secondary bed ${ }^{\circ o c k}$ porosity (fracture porosity) and average fracture aperture associated with high-angle fracturing was dotermined on the basis of the square-array resistivity data. Porosity ranged from 0.0042 to 0.0047 and average fracture aperture ranged from 0.0067 to $0.0073 \mathrm{ft}$. These values do not account for additional porosity that may be associated with horizontal and low-angle fracturing that is present.

In addition to fracture information, seismicrefraction and GPR methods produced depth-tobedrock information that can be used for site characterization. High-resolution cross sections showing small changes in bedrock surface can be produced from seismic-refraction data. Interyretation of the $100-\mathrm{MHz}$ GPR records indicated that the bedrock surface was 0 to $20 \mathrm{ft}$ below land surface for most of the survey. One exception was an indicated depth to bedrock of 45 to $50 \mathrm{ft}$ near lot 34 along Cor estoga Drive. This buried bedrock channel or depression could be a pathway or sink for contamination moving along the bedrock surface. Mapping of the bedrock-surface elevation is needed to determine potential direction of contaminant movement along the surface.

Based on the depth of the 100-MHz radar-wave penetration observed at this site, GPR surveys using higher frequency antennas may produce higher resolution of the bedrock surface, lithology, and possibly the water table than those that were obtained in this study.

Detected and observed fractures in bedrock identified by the geophysical techniques applied in this study were assumed to be water-filled or electrically conductive. These fractures may or may not be hydraulically conductive. Fracture characteristics determined from azimuthal seismic-refraction and azimuthal squarearray resistivity data are representative of high-angle fracturing and do not account for horizontal and low-angle fracturing that also is present. 
Fracture characteristics determined with geophysical methods have been used to develop a preliminary conceptual model of ground-water flow in the bedrock aquifer. If hydraulically conductive, the high-angle fractures and fracture zones detected in this study would provide pathways for ground water and contaminants to enter the bedrock aquifer and subsequently provide pathways for their movement within the bedrock. East-west fracturing would facilitate movement of ground water and contaminants in those directions and vertically into the bedrock aquifer. The north-south fracturing, which the geophysical survey results indicated may only be present at shallow depth, would facilitate north-south movement of ground water and contaminants at shallow depths in the bedrock. Horizontal and subhorizontal fractures may allow ground-water flow in all directions at the depth of the fracture. The present pattern of contamination at the site indicates both east-west and north-south components of movement, but was developed while the pumping stress in the aquifer was increasing and changing direction. Depending on its location and extent, the indicated bedrock channel or depression could be a pathway or sink for contamination moving along the bedrock surface. Verification of this preliminary conceptual model of the bedrock aquifer can be accomplished by detailed site characterization and aquifer testing.

\section{REFERENCES CITED}

Bamford, David, and Nunn, K.R., 1979, In-situ seismic measurements of crack anisotropy in the carboniferous limestone of northwest England: Geophysical Prospecting, v. 27, p. 322-338.

Beres, Milan Jr., and Haeni, F.P., 1991, Application of groundpenetrating-radar methods in hydrologic studies: Ground Water. v. 29 , no. 3, p. 375-386.

Bradley, J.A., and Wright, D.L., 1987, Microprocessor-based data-acquisition system for a borehole radar: Institute of Electrical and Electronic Engineers Transactions on Geosciences and Remote Sensing, GE-24, p. 441-447.

Darboux-Afouda, R., and Louis, P., 1989. Contribution des mesures de l'anisotropic electrique la recherche des aquifres de fracture en milieu cristallin au Benin: Geophysical Prospecting, v. 37, p. 91-105.

Denny. C.S. 1982, Geomorphology of New England: U.S. Geological Survey Professional Paper 1208, 18 p., 1 pl.

Dobrin. M.B., 1976, Introduction to geophysical prospecting (3d ed.): New York, McGraw Hill, 630 p.
Habberjam, G.M., 1972, The effect of anisotropy on square array resistivity measurements: Geophysical Prospecting, v. 20 , p. $249-266$.

1975, Apparent resistivity, anisotropy and strike measurements: Geophysical Prospecting, v. 23, p. $211-247$.

1979, apparent resistivity observations and the use of square array techniques, in Saxov, S., and Flathe, $\mathrm{H}$. (eds.), Geoexploration Monographs, series 1, no. ?, p. 1-152.

Habberjam, G.M., and Watkins, G.E., 1967, The use of square configuration in resistivity prospecting: Geophysical Prospecting, v. 15, p. 221-235.

Haeni. F.P., 1988, Application of seismic-refraction tech niques to hydrologic studies: U.S. Geological Survey Techniques of Water-Resources Investigations, bonk 2, chap. D2, $86 \mathrm{p}$.

Haeni, F.P., Grantham, D.G., and Ellefsen, Karl, 1987a. Microcomputer-based version of SIPT-A program for the interpretation of seismic-refraction data: U.S. Geological Survey Open-File Report 87-103A (text), 13 p. and 87-103B, 5 1/4-inch disk, MS-DOS compatible.

Haeni, F.P., McKeegan, D.K., and Capron, D.R., 1987t. Ground-penetrating radar study of the thickness and extent of sediments beneath Silver Lake, Berlin and Meriden, Connecticut: U.S. Geological Survey WaterResources Investigations Report 85-4108, 19 p.

Holloway, A.L., Stevens, K.M., and Lodha, G.S., 1992, The results of surface and borehole radar profiling from permit area B of the Whiteshell Research Area, Manitoba, Canada, in Hanninen, Pauli and Autio, Sini (eds.), Fourth International Conference on Ground Penetrating Radar: Geological Survey of Finland Snecial Paper 16, p. 329-337.

Hansen, D.A.. Heinrichs, W.E., Jr., Holmer, R.C., MacDougall, R.E., Rogers, G.R., Sumner, J.S., and Ward, S.H., eds., 1967, Mining Geophysics, Vol. II, The rry, Chapter II: Society of Exploration Geophysicists, Tulsa, Okla., 708 p.

HMM Associates, Inc., 1993, Site investigations repor. Kempton Road site, Millville, Massachusetts, June 1993: Prepared for Commonwealth of Massachusetts, Executive Office of Environmental Protection, Bureau of Waste Site Cleanup, Concord, Mass., HMM Associates, Inc., $285 \mathrm{p}$.

Imse. J.P., and Levine, E.N., 1985, Conventional and $s^{*}$ ate of the art geophysical techniques for fracture detection: National Water Well Association Annual Eastern Regional Groundwater Conference, 2nd, Portland, Maine, 1985, Proceedings: Dublin, Ohio, National Ground Water Association, p. 18-36. 
Ivansson, S., 1984, Crosshole investigations-tomography and its application to crosshole seismic measurements: Stockholm, Sweden, Stripa Project IR-84-08.

Lane, J.W. Jr., Haeni, F.P., and Watson, W.M., 1995, Use of square-array direct-current resistivity method to detect fractures in crystalline bedrock in New Hampshire: Groundwater, v. 33, no. 3, p. 476-485.

Lane, J.W. Jr., Haeni, F.P., and Williams, J.H., 1994, Detection of bedrock fractures and lithologic changes using borehole radar at selected sites, in Fifth International Conference on Ground-Penetrating Radar, Kitchener. Ontario, Canada, June 12-16, 1993, Proceedings: Waterloo, Ontario, Waterloo Centre for Groundwater Research, p. 577-591.

Lee, E.T. and Diehl, S.F., 1989, Geomechanical aspects of subsidence in eastern Maine, in Neotectonics of Maine: Maine Geological Survey, Bulletin 40, p. 209-218.

LeMasne, G., 1979, Applications de methodes et electromagnetiques l'etude geophysique des milieus fissures: These 3eme cycle, USTIL Montpelier.

Leonard-Mayer, P.J., 1984a, A surface resistivity method for measuring hydrologic characteristics of jointed formations: U.S. Bureau of Mines Report of Investigations $8901,45 \mathrm{p}$.

1984b, Development and use of azimuthal resistivity surveys for jointed formations, in Nielsen, D.M., and Curl, Mary, (eds.), National Water Well Association/U.S. Environmental Protection Agency Conference on Surface and Borehole Geophysical Methods in Ground Water Investigations, San Antonio, Texas, Proceedings: Dublin, Ohio, National Ground Water Association, p. 52-91.

Lewis, M.R., and Haeni, F.P., 1987, The use of surface geophysical techniques to detect fractures in bedrockan annotated bibliography: U.S. Geological Survey Circular 987, $14 \mathrm{p}$.

Lieblich, D.A., Lane, J.W., and Haeni, F.P., 1991, Results of integrated surface-geophysical studies for shallow subsurface fracture detection at three New Hampshire sites, in Expanded Abstracts with Biographies, SEG 61st Annual International Meeting, Houston, Texas, November 10-14, 1991: Houston, Texas, Society of Exploration Geophysicists, p. 553-556.

Lieblich, D.A., Haeni, F.P., and Cromwell, Rowland, E., 1992a, Integrated use of surface-geophysical methods to indicate subsurface fractures at Tibbetts Road, Barrington, New Hampshire: U.S. Geological Survey Water-Resources Investigations Report 92-4012, 33 p.

Lieblich, D.A., Haeni, F.P., and Lane, J.W. Jr., 1992b, Integrated use of surface-geophysical methods to indicate subsurface fractures at Milford, New Hampshire: U.S. Geological Survey Water-Resources Investigations Report 92-4056, 38 p.
Mallik, S.B., Bhattacharya, D.C., and Nag, S.K., 1983, Behaviour of fractures in hard rocks-A study by surface geology and radial VES method: Geoexploration, v. 21, p. 181-189.

Markt, George, 1988, Subsurface characterization of hazardous waste sites using ground-penetrating radar, in Second International Symposium on Geotechnical Applications of Ground-Penetrating Radar, March 6-10, 1988, Proceedings: $41 \mathrm{p}$.

McDowell, P.W., 1979, Geophysical mapping of water filled fracture zones in rocks: International Association of Engineering Geology Bulletin, v. 19, p. 258-264.

McKniff, J.M., 1964, The petrology of the south half of the Blackstone quadrangle, Massachusetts and Rr ode Island: Providence, R.I., Master's thesis, 37 p.

Mooney, H.M., 1981, Handbook of engineering gesphysics, v. 1.-Seismic: Minneapolis, Minn., Bison Irstruments, Inc., $220 \mathrm{p}$.

Nataraja, M., 1977, In situ stress measurements, P-rk River Project, Hartford, Connecticut: U.S. Departrent of Transportation and U.S. Army Engineer Division, New England, Miscellaneous Paper S-77-22.

Nilsson, B., 1983, A new borehole radar system, in Proceedings of the KEGS symposium on borehole geophysics-mining and geophysical applicetions: Toronto, Canada, $400 \mathrm{p}$.

Niva, Borge, 1993, Results of borehole radar survey in Kempton Road, Millville, Massachusetts: Sw'eden, ABEM GeoScience, unpaginated.

Ogden, A.E., and Eddy, P.S.. Jr., 1984, The use of tri-potential resistivity to locate fractures, faults and caver for siting high yield water wells, in Nielsen, D.M., and Curl, Mary, (eds.), National Water Well Association/U.S.

Environmental Protection Agency Conference on Surface and Borehole Geophysical Methods in Ground Water Investigations, San Antonio, Texas, Proceedings: Dublin, Ohio, National Ground Water Association, p. 130-149.

Olhoeft, G.R., 1984, Applications and limitations of groundpenetrating radar [abs.], in Society of Exploration Geophysicists, 54th Annual International Meeting, Atlanta, Ga., Abstracts: p. 147-148.

1986, Direct detection of hydrocarbon and organic chemicals with ground-penetration radar and complex resistivity, in National Water Well Associaticn Conference on Petroleum Hydrocarbons and Organic Chemicals in Ground Water, Houston, Tex., Proceedings: Dublin, Ohio, National Ground Water Assoc:ation, p. 1-22. 
Olsson, Olle; Andersson, Per; Carlsten, Seje; Falk, Lars; Niva, Borge; and Sandberg, Eric, 1988, Fracture characterization in crystalline rock by borehole radar: Workshop on Ground Penetrating Radar, May 24-26, Ottawa, Canada, 24 p.

1992a, Fracture characterization in crystalline rocks by borehole radar, in Pilon, J. (ed.), Ground penetrating radar: Geological Survey of Canada Paper 90-4, p. 139-150.

Olsson, Olle; Falk, Lars; Forslund, Olof; Lundmark, Lars; and Sandberg, Eric, 1992b, Borehole radar applied to the characterization of hydraulically conductive fracture zones in crystalline rock: Geophysical Prospecting, v. 40, p. 109-142.

Paillet, F.L., and Ollila, Paul, 1994, Identification, characterization, and analysis of hydraulically conductive fractures in granitic basement rocks, Millville, Massachusetts: U.S. Geological Survey Water-Resources Investigations Report 94-4185, 36 p.

Palacky, G.J., Ritsema, I.L., and De Jong, S.J., 1981, Electromagnetic prospecting for groundwater in Precambrian terrains in the Republic of Upper Volta: Geophysical Prospecting, v. 29, p. 932-955.

Park, Stephen, and Simmons, Gene, 1982, Crack induced velocity anisotropy in the White Mountains, New Hampshire: Journal of Geophysical Research, v. 87, no. 84 , p. $2977-2983$.

Redpath, B.B., 1973, Seismic refraction exploration for engineering site investigations: Springfield, Va., National Technical Information Service AD-768710, 51 p.

Risk, G.F., 1975, Detection of buried zones of fissured rock in geothermal fields using resistivity anisotropy measurements, in Geophysical papers submitted to the second United Nations symposium on the development and use of geothermal resources: San Francisco, California, 20-29 May, p. 78-100.

Ritzi, R.W., and Andolsek, R.H., 1992, Relation between anisotropic transmissivity and azimuthal resistivity surveys in shallow fractured carbonate flow system: Ground Water, v. 30, no. 5, p. 774-780.

Rubin, L.A., Fowler, J.C., and Marino, G.G., 1978, Borehole radar: Springfield, Virginia, Ensco Project 114.

Scott, J.H., 1977, SIPT-A seismic inverse refraction modeling program for timeshare terminal computer systems: U.S. Geological Survey Open-File Report 77-365, 35 p.

Scott, J.H., Tibbetts, B.L., and Burdick, R.G., 1972, Computer analysis of seismic refraction data: U.S. Bureau of Mines Report of Investigation 7595, $95 \mathrm{p}$.

Sehli, A.S., 1990, Contribution of electrical prospecting to the geophysical study of discontinuous media, in International symposium on applications of geophysics to water prospecting in arid and semi-arid areas, Paris, France.
Sheriff, R.E. 1984, Encyclopedic dictionary of exploration geophysics, (2d ed.): Tulsa, Okla., Society of Exploration Geophysics, 323 p.

Soonawala, N.M. and Dence, M.R., 1981, Geophysics in the Canadian nuclear waste program-A case history: Society of Exploration Geophysicists Annual International Meeting, 51st, Los Angeles, Calif., IC 1 . Proceedings, p. 83-98.

Taylor, R.W., 1982, Evaluation of geophysical surface methods for measuring hydrological variables in fractured rock units: U.S. Bureau of Mines Research Contract Report, contract H0318044, 147 p.

1984, The determination of joint orientation and porosity from azimuthal resistivity measurements, in Nielsen, D.M., and Curl, Mary (eds.), National Wa+er Well Association/U.S. Environmental Protection Agency Conference on Surface and Borehole Geophysical Methods in Ground Water Investigations, San Antenio, Texas: Dublin, Ohio, National Ground Water Association, Proceedings, p. 37-49.

Taylor, R.W., and Fleming, A.H., 1988, Characterizing jointed systems by azimuthal resistivity surveys: Ground Water, v. 26 , no, 4 , p. $464-474$.

Trabant, P.K., 1984, Applied high-resolution geophysical methods: Boston, International Human Resources Development Corp., 265 p.

Ulriksen, P.F., 1982, Application of impulse radar to civil engineering: Lund, Sweden, Lund University of Technology, Ph.D. Thesis, 179 p.

Wright, D.C., Olhoeft, G.R., Watts, R.D., 1984, Groundpenetrating radar studies on Cape Cod, National Water Well Association-U.S. Environmental Protection Agency Conference on Surface and Borehole Geophysical Methods in Ground Water Investigations, February 7-9, 1984, San Antonio, Texas: Dublin, Ohio, National Ground Water Association, Proceedings, p. 666-680.

Wright, D.L., and Watts, R.D., 1982, A single-hole, shotpulse radar system, in Geophysical investigations in connection with geological disposal of radioactive waste: Ottawa, Canada, OECD/NEA, 317 p.

Zen, E-an, [ed.], Goldsmith, Richard, Ratcliff, N.L., Robinson, Peter, and Stanley, R.S., [compilers],1983, Bedrock geologic map of Massachusetts: U.S. Geological Survey, Washington, D.C., 3 sheets, scale 1:250,000.

Zody, A.A.R., Eaton, G.P., and Mabey, D.R., 1974 [1984], Application of surface geophysics to ground-water investigations: U.S. Geological Survey Techniques of Water-Resources Investigations, book 2, chap. D1, 116 p. 